\title{
The impact of carbon disclosure mandates on emissions and financial operating performance
}

\author{
Benedikt Downar ${ }^{1}$ • Jürgen Ernstberger ${ }^{1}$ - Stefan Reichelstein ${ }^{2,3}$. \\ Sebastian Schwenen ${ }^{1}$ (D) Aleksandar Zaklan ${ }^{4}$
}

Accepted: 1 June 2021/Published online: 05 August 2021

(C) The Author(s) 2021

\begin{abstract}
We examine the impact of a disclosure mandate for greenhouse gas emissions on firms' subsequent emission levels and financial operating performance. For UK-incorporated listed firms a carbon disclosure mandate was adopted in 2013. Our difference-indifferences design shows that firms affected by the mandate reduced their emissions by about $8 \%$ relative to a control group of European firms. At the same time, our tests indicate that the treated firms experienced no significant changes in their gross margins. Taken together, our findings indicate that the reporting mandate had a real effect on the variable to be disclosed without adversely affecting the financial operating performance of the treated firms.
\end{abstract}

Keywords Disclosure of nonfinancial information - Mandatory disclosure - Greenhouse gas emissions $\cdot$ Real effects

JEL Classification Q28·Q40 · M41 · M48

\section{Introduction}

Climate change is widely regarded as one of the most vexing societal challenges of our time. The root cause of this challenge is the fundamental externality that arises when

\footnotetext{
An earlier version of this paper was titled "Fighting Climate Change with Disclosure? The Real Effects of Mandatory Greenhouse Gas Emission Disclosure." This paper has benefited from insightful comments by Stephen Penman (the editor), two anonymous reviewers, Naomi Soderstrom (discussant), Jan Abrell, Irma Malafronte (discussant), Helene Naegele, Thorsten Sellhorn as well as participants at the Review of Accounting Studies conference, the Annual Congress of the European Accounting Association, the World Congress of Environmental and Resource Economists, the VHB Congress, and seminar participants at the universities Erlangen-Nuremburg, Copenhagen, Mannheim, Mainz, St. Gallen, Oldenburg, and Passau. Reichelstein thanks the DFG under grant TRR-266 for partial financial support.
}

Sebastian Schwenen

sebastian.schwenen@tum.de

Extended author information available on the last page of the article 
economic subjects do not internalize the full social cost of their greenhouse gas (GHG) emissions. The continuing mismatch between the private and social costs of GHG emissions has arguably resulted in a large-scale global market failure. ${ }^{1}$ Policymakers have begun to counteract this mismatch through a range of policy tools, such as carbon pricing and direct emissions regulations. ${ }^{2}$ At the same time, relatively little is known about the potential impact of a disclosure mandate that merely requires firms to report their carbon footprint without any obligation to reduce these emissions over time. ${ }^{3}$

A central axiom in management accounting, dating back to Drucker (1954), postulates that "what gets measured, also gets managed." Inside firms, this linkage is plausible and well-documented to the extent that the variable of interest is included in the firm's performance evaluation and incentive system. ${ }^{4}$ The linkage between measurement and subsequent improvements becomes more tenuous in a market setting where firms disclose the variable of interest to the general public. It appears plausible that a mere requirement to report carbon emissions will "incentivize" firms to improve upon their subsequent emissions (even though such improvements are costly), provided that firms also anticipate being "rewarded" by different stakeholder groups for these improvements.

Numerous studies on Corporate Social Responsibility (CSR) and Environmental, Social and Governance (ESG) activities have observed that improvements in outcome variables are often difficult to establish because there is no commonly accepted measurement framework, e.g., labor practices that are deemed sustainable. ${ }^{5}$ The lack of a well-defined measurement framework also makes it difficult, if not practically impossible, to have subsequent outcomes verified by third parties. ${ }^{6}$ In these respects, greenhouse gas emissions are a relative exception, as they involve physical measurements, the delineation of scope (e.g., so-called Scope 1 or Scope 2 emissions), and an aggregate score for multiple greenhouse gases in order to arrive at a measure of $\mathrm{CO}_{2}$ equivalents.

The main hypothesis examined in this paper is whether mandatory reporting entails a real GHG emission reduction effect, possibly because of stakeholder pressure on firms to subsequently "manage" —in the sense of Drucker (1954) — their carbon emissions. It seems plausible that firms will do so because multiple stakeholder groups, including customers, employees, and investors, regard corporate emissions as a negative firm attribute. In that sense, a disclosure mandate may create a "pillory" with regard to a firm's carbon footprint. ${ }^{7}$ As firms can point to improvements with regard to

\footnotetext{
${ }^{1}$ The so-called Stern Review (Stern 2006) famously refers to climate change as "the greatest market failure ever seen."

${ }^{2}$ See Ellerman et al. (2010), Anderson and Di Maria (2011), Bel and Joseph (2015), Murray and Maniloff (2015), and Martin et al. (2016).

${ }^{3}$ As discussed in more detail below, contemporaneous papers by Tomar (2019), Jouvenot and Krueger (2020), and Grewal (2021) also examine the real effects of carbon disclosure mandates.

${ }^{4}$ See, for instance, Young and O’Byrne (2001) and Kaplan and Anderson (2007).

${ }^{5}$ See, for instance, Christensen et al. (2017), Fiechter et al. (2020), Grewal et al. (2019), and Grewal and Serafeim (2020) for a comprehensive assessment of the many recent studies on corporate sustainability management.

${ }^{6}$ Kanodia (2007) develops a model framework in which the designer faces a trade-off in setting a precision standard for disclosures due to the real (investment) effects that emerge in the ensuing market equilibrium.

${ }^{7}$ A particular firm-level outcome variable, like pollution, that is publicly known and viewed as a negative by investors is also the central feature in the models of Heinkel et al. (2001) and Friedman and Heinle (2016).
} 
this publicly reported "bad" in the future, they will arguably improve their standing with different stakeholder groups. ${ }^{8}$

Our study evolves around the Companies Act 2006 (Strategic Report and Directors' Report) Regulations 2013. This act imposed a mandate on publicly listed UKincorporated firms to report their GHG emissions as part of their annual financial reports. Prior to this mandate, companies had an obligation to gather and report the emissions of their individual installations (i.e., production sites such as power plants or steel mills) that were regulated under the European Union Emissions Trading System (EU ETS) to a publicly available register. ${ }^{9}$ Prior to 2013 , there was no obligation for publicly listed UK firms to report their overall "carbon footprint" as the aggregate of their installation-level emissions in the annual corporate report. In that sense, the regulation increased transparency, as interested parties no longer had to trace emission figures at the installation level back to the parent companies owning the installation.

To examine the impact of the UK GHG emission disclosure mandate on subsequent emissions and financial performance, we adopt a difference-in-differences (DiD) approach surrounding the implementation of the Companies Act. We compare the difference between pre- and post-mandate emission data for affected firms with emission data for a sample of control firms. In our study, this comparison is made feasible by tracing the emissions of all installations, as reported to the central EU ETS registry, back to the firms in our sample for a ten-year time window around the year 2013. The treatment group in our DiD design consists of installations that are located in the UK or another European country but are ultimately owned by UK-incorporated, publicly listed companies. ${ }^{10}$ The control group consists of installations that are ultimately owned by companies not subject to the 2013 act — that is, publicly listed firms in other EU countries.

Our results provide evidence of a significant reduction in GHG emissions following the disclosure mandate for firms in the treatment group relative to the control group. The effect is sizable insofar as firms subject to the mandate, on average, reduce their GHG emissions by about $8 \%$ between the pre- and the post-mandate periods.

The 2013 UK mandate also requires firms to disclose a carbon intensity variable that expresses total $\mathrm{CO}_{2}$-equivalent emissions in relation to some activity measure such as output, cost, or revenues. Such a ratio measure will be more informative about actual emission improvements for firms that have experienced substantial growth or contraction over time. We estimate the effect of the disclosure mandate on firms' carbon intensity by considering both sales and cost of goods sold (COGS) as the activity variable in the denominator. We find that the firms in the treatment group exhibit a significant incremental reduction in carbon intensity of approximately $13 \%(10 \%)$ when the denominator in the carbon

\footnotetext{
${ }^{8}$ Prior studies document real effects of disclosure regulation on investment (Biddle and Hilary 2006; Biddle et al. 2009; Graham et al. 2011; Cheng et al. 2013; Shroff et al. 2014; Shroff 2017), mine safety Christensen et al. (2017), and managerial short-termism (Ernstberger et al. 2017; Granja 2018; Kraft et al. 2018).

${ }^{9}$ The EU Transaction Log records yearly emissions from all installations regulated under the EU Emissions Trading System.

${ }^{10}$ Our study focuses on data of all installations covered by the EU ETS, i.e., emissions within the 27 member states of the European Union and Norway. Since data on installations in other countries is not available, we cannot rule out carbon leakage between firms' European and non-European installations. However, Dechezleprêtre et al. (2019) find no evidence of carbon substitution effects across countries.
} 
intensity ratio is COGS (sales). Finally, we provide evidence that our results are robust to alternative empirical design choices, to reliance on a balanced rather than unbalanced sample, and to a matched-sample approach.

The magnitude of the reduction in emissions and carbon intensity may appear surprising for two reasons. First, as mentioned above, the information about Scope 1 emissions at the level of individual installations was already available prior to the 2013 mandate, albeit in dispersed form. As such, the mandate arguably only "pilloried" the treated firms to the extent that firm-level emissions became more accessible and transparent. Second, more than two-thirds of the treated firms in our sample participated in the Carbon Disclosure Project (CDP), which provides a global forum for firms and/or their subsidiaries to supply voluntary information about their GHG emissions and ongoing efforts to reduce them. ${ }^{11}$ There are no binding reporting standards or informational requirements for disclosures submitted to the CDP. A reflection of this lack of formal requirements is that the CDP rates the participating firms with a score regarding the credibility and comprehensiveness of their voluntary disclosures. One way to interpret the UK GHG reporting mandate is that the obligation to report total corporate Scope 1 and 2 GHG emissions forced the unravelling of a partial disclosure equilibrium that was in effect prior to 2013.

With regard to the financial impact of the 2013 disclosure mandate, it would be surprising to find that the regulation had improved the financial operating performance of the treated firms. If firms had anticipated such beneficial effects, they could have precommitted to provide information on emission reductions in their annual reports. Thus, one would expect that abnormal efforts to reduce GHG emissions are costly. Firms can reduce emissions in the short and medium run through a range of measures, including input substitutions and the outsourcing of carbon intensive activities. The well-known study by McKinsey (2009) suggests that some industries may have access to low-cost abatement options, such as installation retrofits. ${ }^{12}$ Yet, there does not seem to be a general understanding of the abatement potential (in terms of tons of $\mathrm{CO}_{2}$ saved) of these low cost options.

Any cost increases associated with abnormal carbon reduction efforts could be partially offset by higher sales. Such revenue increases could simply reflect pricing power that allows firms to pass on the increase in their production costs. At the same time, and in line with our notion of "stakeholder pressure," any differential increase in sales could also reflect that firms reporting significant carbon emission reductions in their annual reports attain greater loyalty from their customers.

Testing the hypothesis of a net-zero effect on revenues and cost, our DiD analysis shows that the treated firms do not experience a significant incremental impact in terms of their gross margins following the 2013 regulation. In separate explorations of the overall effect of the mandate on financial operating performance, our regression results indicate that the treated firms exhibit a small, but statistically insignificant, increase in both production costs and sales relative to the firms in the control group. The same conclusion emerges for capital expenditures that may have been undertaken to achieve

\footnotetext{
${ }^{11}$ Broadstock et al. (2018) point to the endogeneity issues that have afflicted empirical studies on voluntary corporate disclosures of GHG emissions.

12 The 2018 IPCC report discusses the abatement potential of different options.
} 
the emission reductions. Taken together, our findings indicate that the disclosure requirement for publicly listed UK firms does not lead to a deterioration in their financial operating performance.

The final part of our analysis explores cross-sectional variation among the treated firms in their response to the disclosure requirement. In this part, we exploit the information available at the individual installation rather than the aggregate firm level. Specifically, we construct a complexity index that ranks firm heterogeneity in terms of the number of installations firms operate, the percentage of emissions these firms incur abroad, and the number of sectors in which firms are active. Our findings indicate that firms with a higher complexity score tend to reduce emissions at a lesser rate than their less complex counterparts.

Several other contemporaneous studies have examined the effects of mandatory reporting on corporate GHG emissions. Closest to our study are papers by Jouvenot and Krueger (2020), Grewal (2021), and Tomar (2019), the first two of which also focus on the UK disclosure mandate for GHG emissions in 2013. To quantify the impact of the mandate on subsequent emission levels, Jouvenot and Krueger (2020) rely on voluntarily disclosed information in the CDP database and on emission estimates issued by private organizations that track corporate GHG emissions. In contrast, our analysis relies on the granular, time-consistent, and verified data provided to the European Union Transaction Log (EUTL) register at the level of individual production sites, both prior to and after the mandate. Beyond the impact of the mandate on actual emissions, our study examines the impact on financial operating performance, while Jouvenot and Krueger (2020) study the consequences of the mandate on investments by large institutional investors, on media coverage, and on stock prices.

In a study complementary to ours, Grewal (2021) focuses on firms that were already reporting information about their carbon emissions to the Carbon Disclosure Project (CDP). Grewal (2021) establishes that, following the 2013 regulation, the subset of treated UK firms reports larger emission reductions than their counterparts not subject to the regulation. Furthermore, the incremental effect is more pronounced for firms with a relatively high level of pre-mandate emissions. These findings are consistent with our interpretation that the reporting mandate has an additional "pillory effect" beyond the information that firms already disclosed through channels like the CDP. In contrast to our approach, though, Grewal's (2021) analysis considers self-reported emission levels both before and after the mandate, rather than the emission figures verified under the European ETS system.

Tomar (2019) studies the effect of a regulation that obligates large US production facilities to report their emissions to the US Environmental Protection Agency. In contrast to the UK regulation, however, there was, and still is, no requirement that US firms disclose their emissions in the aggregate as part of the annual report. Thus, the post-mandate disclosure requirement in Tomar's study is similar to the pre-mandate setting that UK firms faced on account of the EU ETS regulations prior to the 2013 act. Regarding pre-treatment emission levels, Tomar (2019) develops an estimation technique for both the treatment and the control group. At the same time, Tomar's main conclusions, like those of the other two studies discussed above, are broadly consistent with our first result that a disclosure mandate resulted in a significant reduction in subsequent GHG emissions. 
Beyond the issue of GHG emissions, our study adds to the broader literature on the real effects of disclosure mandates regarding environmental and hazardous outcomes. Christensen et al. (2017) provide evidence that the Dodd-Frank Act provision requiring firms engaged in natural resource extraction to report on mine accidents and citations on mines in their annual reports did lead to improved worker safety in the mines of the regulated firms. ${ }^{13}$ In another recent study, Chen et al. (2018) show that mandatory CSR reporting decreases local pollution levels, i.e., wastewater and sulfur dioxide $\left(\mathrm{SO}_{2}\right)$ emissions, in Chinese cities in which firms affected by the CSR mandate are located. Chen et al. also argue that the CSR mandate was associated with a decrease in firms' accounting rates of return.

Similar to the setting in Christensen et al. (2017) and Chen et al. (2018), our central hypothesis is that the disclosure mandate increases transparency and thereby creates pressure on management to improve the outcome variable in question. In case of mine safety or local environmental pollution, the hypothesized "pillory effect" is highly plausible because the reported information will be of interest to local media outlets and analysts. In contrast, with global pollution, the intensity of stakeholder pressure is less clear because the costs associated with GHG pollution, and therefore the benefits of reducing them, are distributed globally and thus affect local stakeholders only proportionally. $^{14}$

The remainder of this paper proceeds as follows. Section 2 introduces the regulatory background and develops the hypotheses to be tested. Section 3 describes the research design. Section 4 presents the results. Section 5 presents sensitivity and additional analyses. We conclude in Section 6.

\section{Regulatory background and hypothesis development}

\subsection{Regulatory background}

The Companies Act 2006 (Strategic Report and Directors' Report) Regulations 2013 were presented to the UK Parliament by the Department for Business, Innovation and Skills (BIS) in June 11, 2013. The act was published in August 2013 and came into effect on October 1, 2013. Accordingly, "listed companies" are required to disclose their direct and indirect GHG emissions in their annual reports. Section 385 (2) of the act defines a listed company as a UK-incorporated company whose equity shares are listed on the Main Market of the London Stock Exchange, an exchange in a European Economic Area state, the New York Stock Exchange, or Nasdaq. The act applies to all fiscal years ending on or after September 30, 2013.

In particular, the 2013 act requires that companies disclose, in the Directors' Report, their direct (Scope 1) and indirect (Scope 2) GHG emissions during the last 12 months.

\footnotetext{
${ }^{13}$ As in our study, the information to be reported annually was already public prior to the regulation, since firms had to report it to the Mine Safety and Health Administration. In that sense, the disclosure mandate merely highlighted an individual firm's performance with regard to the outcome variable.

${ }^{14}$ Prior literature has established that $\mathrm{SO}_{2}$ is a local hazard affecting human health outcomes and agricultural yields (Muller et al. 2011; EPA 2019), while $\mathrm{CO}_{2}$ constitutes a non-toxic, yet global long-term threat to the stability of the world's climate. In that sense, the effects of $\mathrm{SO}_{2}$ are significantly different from those of GHG emissions like $\mathrm{CO}_{2}$.
} 
Direct emissions are those caused by the combustion of fuels and the operation of production facilities. Indirect emissions are those resulting from the purchase of electricity, heat, steam, or cooling. The following greenhouse gases are to be included in the report: carbon dioxide $\left(\mathrm{CO}_{2}\right)$, methane $\left(\mathrm{CH}_{4}\right)$, nitrous oxide $\left(\mathrm{N}_{2} \mathrm{O}\right)$, hydrofluorocarbons (HFCs), perfluorocarbons (PFCs), and sulfur hexafluoride $\left(\mathrm{SF}_{6}\right)$. Companies are not required to provide individual emission figures for each of the greenhouse gases listed. Instead, they are asked to report the aggregate annual quantity of $\mathrm{GHG}$ emissions in $\mathrm{tCO}_{2} \mathrm{eq}$, with the weights determined according to the weights set by the Intergovernmental Panel on Climate Change. ${ }^{15}$ In addition to the total Scope 1 and Scope $2 \mathrm{tCO}_{2} \mathrm{eq}$, companies must report a carbon intensity metric that relates emissions to some activity measure such as sales or cost of goods sold.

In addition to GHG emissions, the act imposes disclosure requirements pertaining to the diversity of directors, senior managers, and other employees as well as broader social and human rights issues. UK companies also face new obligations to report on environmental matters and developments that are likely to affect their business in the future. In Appendix A, we provide an overview of the new reporting items. While there is no indication that any of these reporting requirements confound our results, we cannot rule out that the broader environmental reporting mandate might also have influenced the propensity of the UK firms to reduce their carbon emissions.

The GHG disclosure mandate does not prescribe a specific method for calculating GHG emissions, but it requires the use of "robust and accepted methods" (DEFR 2013) and recommends a "widely recognized independent standard" (DEFR 2013). It encourages companies to "use relevant information from other domestic and international regulatory reporting processes" (DEFR 2013), such as data collected through the EU Emissions Trading Scheme (EU ETS), the approach taken in this study.

The data collected under the auspices of the EU ETS is publicly available in the European Union Transaction Log (EUTL) register, which provides information at the installation level, including its identification, operator, NACE code, and the activity type it is assigned to in the EU ETS (e.g., production of bulk chemicals or combustion of fuels). We refer to the emissions reported to the EUTL as actual (Scope 1) emissions. While the actual volume of GHG in the flue gases of a particular facility is inherently difficult to track in real time, we view the detailed Monitoring, Reporting and Verification (MRV) framework adopted by the European Union as a fairly precise method for determining actual emissions. Specifically, the MRV regulations describe (i) the allowable method for calculating the emissions by different facilities given their activity levels (Monitoring), (ii) the firms' reporting requirements (Reporting), and (iii) the external parties that national regulators can accredit as verifiers (Verification). Finally, the reported and verified emissions are subject to confirmation by an independent reviewer. These detailed regulations are intended to prevent underreporting of emissions by firms, which would allow them to purchase fewer emission allowances. This standardized measurement appears to have been unchanged in the years surrounding the UK disclosure mandate.

\footnotetext{
${ }_{15}$ The UK Government publishes the conversion factors for $\mathrm{GHG}$ emissions to $\mathrm{CO}_{2}$ equivalents on an annual basis. These factors are generally consistent with IPCC guidelines and the regulations under the EU ETS. The report must be approved by the board of directors and reviewed by the statutory auditor, while compliance with the act is enforced by the UK Financial Reporting Council. Directors of the affected firms face fines for being reckless or failing to take reasonable steps to ensure compliance (paragraph 415, (4) and (5) of the act).
} 
Since its introduction in 2005, the EU ETS has become the world's largest multinational emissions trading system. ${ }^{16}$ This cap-and-trade mechanism covers industries that account for about 45\% of the European Union's GHG emissions (Ellerman et al. 2016). ${ }^{17}$ The remaining emissions not covered under the ETS system come primarily from the transportation, residential, and agricultural sectors (DECC 2016). Installations are covered by the EU ETS if they include a facility with a rated thermal input of at least $20 \mathrm{MW}$ - enough to supply about 15,000 households with electricity at a given point in time - or if they fall into one or several of the following manufacturing segments: oil refineries, coke ovens, iron and steel, cement clinker, glass, lime, bricks, ceramics, pulp, paper and board, aluminum, petrochemicals, ammonia, nitric, adipic and glyoxylic acid production (European Commission 2015). Due to these rules, EU ETS coverage is concentrated in the sectors of energy supply and industrial manufacturing, covering approximately $79 \%$ of all UK emissions in 2014. Finally, note that the implementation of the act took place in the same year as the transition of the EU ETS to its third trading period, which covered the years $2013-2020{ }^{18}$ The underlying scheme generating the emission data used in this paper hence spans two trading periods, and the transition to the third period took place concurrently to the introduction of the act. In Appendix B, we discuss these concurrent changes in more detail. We believe none affects our treatment and control group differentially.

Annual emissions by installations vary widely, ranging from a few thousand tons per year at small installations to several million tons at large coal power plants. The average (mean) UK installation covered by the EU ETS had emissions of about 100,000 tons of $\mathrm{CO}_{2}$ equivalents during our sample period.

From an inference perspective, there are several benefits to our approach of tracking direct (Scope 1) GHG emissions from individual installations according to the EU ETS data. Most importantly, the reported figures were measured and audited consistently both before and after the UK disclosure mandate went into effect. Unlike other studies, such as Tomar (2019), we therefore do not have to estimate a firm's emissions prior to the reporting mandate. In the context of our disclosure study, there is an additional advantage to focusing on Scope 1 emissions as the outcome variable. As explained in more detail in Section 3.5, UK power producers were subject to sector-specific emission charges and therefore had additional financial incentives to reduce their Scope 1 emissions during our observation window. Any such improvements will therefore carry through as improvements in the Scope 2 emissions of UK based installations that purchase electricity from the grid. If emissions are measured as the total of Scope 1 and Scope 2 emissions, a reduction in a firm's carbon emissions after the mandate could therefore be merely the result of lower Scope 1 emissions by the upstream electricity producers.

\footnotetext{
${ }^{16}$ Emission trading systems similar to the EU ETS have also been introduced in a few other jurisdictions. In the US, the California cap-and-trade scheme covers GHG emissions from power generation and industrial activities of facilities based in California (Air Resources Board 2016), and the Regional Greenhouse Gas Initiative covers emissions from electricity production in nine Northeastern and Mid-Atlantic states (RGGI 2013).

${ }^{17}$ For our sample country, the UK, the EU ETS covers a similar share of total emissions. For instance, in 2014, the first full year after the introduction of the disclosure rule, the EU ETS covered about $41 \%$ of total UK emissions. In 2014, total UK emissions were 514 million tons of $\mathrm{CO}_{2} \mathrm{eq}$, while the sum of verified emissions of all UK installations in the UK was 208 million tons of $\mathrm{CO}_{2}$ eq (DECC 2016).

${ }^{18}$ The first trading period covered the years 2005-2007, while the second encompassed 2008-2012.
} 
To examine changes in emissions at the firm level, we assign all installations to their respective owners and aggregate the emissions data at the installation level for each firm. As illustrated in Fig. 1, the mapping from installations to firms (mathematically, a function) is carried out for both the treated UK-headquartered firms and the control group of firms that were not subject to the mandate.

We emphasize that in the context of our study the disclosure mandate did not make additional information publicly available, as the emissions of the treated firms were already accessible to the general public, albeit in a rather fragmented form, through the EUTL register. In essence, the informational effect of the disclosure mandate was to increase transparency, because an interested observer no longer had to carry out the mapping shown in Fig. 1 to calculate a firm's overall Scope 1 emissions.

\subsection{Hypothesis development}

The hypotheses tested in this paper pertain both to changes in GHG emissions and to changes in the financial operating performance of the firms subject to the UK disclosure mandate. Broadly, our approach is consistent with the so-called targeted disclosure cycle theory (Fung et al. 2007). Accordingly, disclosures influence the behavior of receivers (stakeholders), leading to real effects in the variables to be disclosed in the future. The information providers anticipate these behavioral changes and take actions that enable more favorable disclosures.

In a recent survey article, Hombach and Sellhorn (2019) lay out a set of criteria for corporate reporting mandates to have real effects, that is, effects on the variables that are being disclosed. Aside from sufficiently precise reporting standards and compliance requirements, the reporting variables in question must generate additional public information, or at least increase transparency about the variable in question. In order for real effects to emerge from a reporting mandate, Hombach and Sellhorn (2019) also posit that the disclosed information must be broadly value relevant, possibly by illuminating potential future risks to the business. Finally, management must have both the discretion and the motivation to subsequently improve the outcome variable.

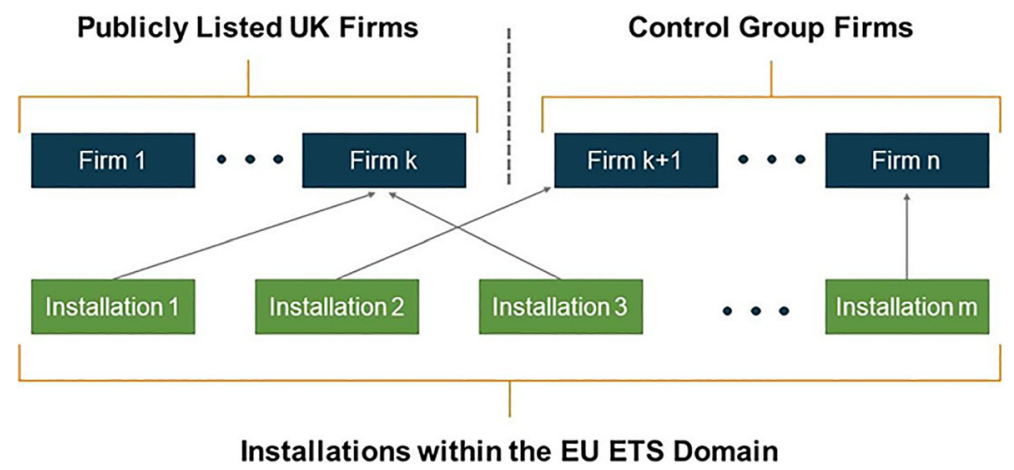

Fig. 1 Mapping of installations to firms. This figure shows the mapping of data at the installation level (as reported in the EU ETS) to treatment and control group firms. Using information on the (ultimate) owner of each installation, we map installations to either a treatment or a control group firm. The link between the installation owner and the ultimate owner (i.e., firm in our sample) is established by the Ownership Links and Enhanced EUTL Dataset Project (OLP), which provides the name and Bureau-van-Dijk identification number of an installation's ultimate parent company 
The preceding criteria all appear to be met by the UK 2013 disclosure mandate. In addition to a specific reporting standard and the prospect of enforcement, it is plausible that multiple stakeholder groups of the treated firms, including customers, employees and capital providers, view the firm's carbon footprint as a negative. Because of the externality associated with the firm's emissions on the world's climate, these constituents would intrinsically prefer a lower carbon footprint, though they are likely to understand that certain emissions levels are unavoidable in the short run if the firm is to remain competitive in its product markets.

If the firms subject to the 2013 carbon disclosure mandate did indeed reduce their emissions more than the control group, the natural follow-on question is whether these efforts had a tangible impact on financial operating performance. On the benefit side, firms may anticipate that potential production cost increases can at least be partially passed on to consumers. While the possibility of pass-through generally depends on a firm's cost structure and pricing power, a tangible reduction in publicly reported carbon emissions will arguably improve the firm's public image. That, in turn, may lead to greater customer loyalty and thus a lower price elasticity of demand for customers who regard the firm's carbon footprint as a negative attribute. ${ }^{19}$ From that perspective, emission reductions in the interest of "stakeholder capitalism" would at least be partially aligned with the interests of shareholders.

Another stakeholder group that may react favorably to improvements in reported carbon emissions are the firm's employees. For the same reasons as articulated in connection with customers, some employees will be intrinsically concerned about the climate-damaging effects of the firm's emissions. This group will tend to identify more strongly with an organization that can publicly and credibly claim to be innovative and progressive on the issue of climate change. To the innovating firms, the potential benefit from such an improvement in public perception is that ceteris paribus less compensation may be required to retain valued employees.

Finally, management of the firms in our treatment group may anticipate penalties by the capital markets unless improvements in carbon emissions can be claimed in the time periods following a disclosure mandate. In recent years, institutional equity investors have become increasingly vocal that meaningful sustainability practices are becoming a major criterion for the inclusion of firms in their portfolios. A potential penalty for firms that are viewed as stagnant in their emission levels (or other sustainability activities) is that they may be "shunned" by some investor groups, leading to an increase in their cost of equity capital. ${ }^{20}$ Kraus and Amir (2010) and Friedman and Heinle (2016) develop formal models wherein investors, in equilibrium, effectively exert pressure on management to improve a firm's sustainability practices. ${ }^{21}$ The preference structure of these institutional investors may directly reflect the intrinsic preferences of their capital providers. Some institutional investors have also explicitly stated that they view sustainability practices as an effective mitigation strategy with

\footnotetext{
$\overline{19}$ Reichelstein and Hoyt (2011) argue that this linkage was important for management at the outdoor equipment retailer REI in setting sustainability targets, including a substantial carbon footprint reduction.

${ }^{20}$ A widely reported illustration of such "penalties" was provided by the CEO of BlackRock, Larry Fink, in his annual letter to CEOs in 2020, when he stated, "We will be increasingly disposed to vote against management and board directors when companies are not making sufficient progress on sustainabilityrelated disclosures and the business practices and plans underlying them" (Sprouse 2020).

${ }^{21}$ Disclosure is not an issue in these models, as the CSR variable of interest is assumed to be publicly known.
} 
regard to future financial risks, specifically the risk of carbon intensive assets becoming economically impaired. ${ }^{22}$

Arguments suggesting that the real effect of the UK mandate could be minor include the possibility that the added transparency resulting from the disclosure requirement was inconsequential insofar as concerned parties could already access the EU transaction log prior to the mandate. Furthermore, with some additional information gathering effort, interested parties could trace the emissions from individual installations back to the parent companies owning the installations (Fig. 1).

We also note that a substantial share of the treatment firms in our sample did already report information about their GHG emissions to the Carbon Disclosure Project prior to 2013. These disclosures, however, are neither subject to binding reporting standards nor verified by a third party. ${ }^{23}$ Participation in the CDP has always been voluntary and therefore reflects self-selection by the participating firms. ${ }^{24}$ Nonetheless, as emphasized in Grewal's (2021) study, these disclosures may already have conveyed material firmlevel information about emissions ahead of the act. ${ }^{25}$ Finally, while the treated firms may indeed have perceived their annual emissions reports as a "pillory," the actual reduction potential available to them in the short and medium run, i.e., over a period of five or six years in our post-mandate observation window, may have been limited. This may be especially plausible because many of the treated firms were already subject to carbon pricing under the EU ETS system and therefore already had an incentive to adjust their production processes in the direction of more energy- and carbonefficiency.

Mindful of the preceding countervailing considerations, we nonetheless state the following hypothesis.

\section{H1: Firms subject to the UK mandate for annual disclosure of GHG emissions attain a larger reduction in their Scope 1 emissions than firms not subject to the mandate.}

The Companies Act 2006 (Strategic Report and Directors' Report) Regulations 2013 also require firms to disclose a carbon intensity variable that relates raw emissions of $\mathrm{CO}_{2}$ equivalents to a meaningful indicator of production activity. Thus, the carbon intensity variable should indicate whether a reduction in emissions can be attributed to a mere reduction in production volume, or, conversely, whether an increase in

\footnotetext{
$\overline{22}$ The belief that long-term value maximization requires management practices that are environmentally and socially sustainable is emphasized, for instance, by investment funds like Generation Investment Capital (Reichelstein and Bebb 2016).

${ }^{23}$ A survey of UK equity fund managers shows that the lack of detailed requirements concerning reporting methodologies and organizational boundaries, as well as the lack of a third-party audit or review, was an important barrier for their reliance on voluntary GHG emission data (Trucost 2009).

${ }^{24}$ Examining voluntary carbon disclosure in the UK retail sector, Sullivan and Gouldson (2012) indicate that voluntary disclosure limits investors' ability to assess corporate climate performance due to different scopes of reporting and inconsistencies in the information being reported. In addition, DEFRA (2010) states that "even though CDP data is widely regarded as the most complete and comprehensive dataset on climate disclosure, many question quality of data as an issue which is inevitable with any voluntary disclosure scheme not requiring third party verification."

25 According to a survey of PricewaterhouseCoopers (PwC) in partnership with the Carbon Disclosure Project (CDP), voluntary reporting of GHG emissions by a company raised the awareness of emissions for the board of directors, employees and the general public (PwC and CDP 2010).
} 
emissions can be attributed to production growth. For the denominator in the carbon intensity measure, we consider both sales and cost of goods sold, noting that, for the firms in our treatment group, both of these variables were arguably affected by the disclosure mandate of 2013. In direct analogy to hypothesis H1, we hypothesize that the UK disclosure mandate of 2013 also had a real effect on the carbon intensity of the treated firms.

H2: Firms subject to the UK mandate for annual disclosure of GHG emissions attain a larger reduction in their carbon intensity than firms not subject to the mandate.

Our next hypothesis pertains to the financial performance of the treated firms. In order to reduce their carbon footprint, firms will presumably incur higher production costs. The magnitude and shape of the individual abatement cost curves, however, appear difficult to gauge, and are likely to vary considerably by industry. Several emission reduction measures will conceivably be available to firms in the manufacturing sector in the short and medium run. For instance, onsite fossil fuel power plants can be idled, with the requisite power and heat then procured from outside vendors. This would induce a shift from Scope 1 to Scope 2 emissions, with firms likely to care primarily about their "own" Scope 1 emissions. ${ }^{26}$

Additional reduction measures include possible input substitutions that reduce the reliance on carbon-intensive materials like coal. For production processes requiring high operating temperatures, for instance, firms in carbon-intensive industries like steel and cement can switch from using coal or oil as a heating agent to electricity or less carbon-intensive agents like natural gas or hydrogen. Finally, holding output and production processes constant, many businesses will be in a position to reduce their fossil-fuel consumption and, thus, their emissions through investments in equipment that is more energy efficient.

The impact of alternative carbon reduction measures on overall manufacturing costs has to date not been estimated reliably at the level of individual industries. The carbon abatement curves by McKinsey (2009) suggest that, for moderate GHG reductions, firms will be able to identify considerable "low hanging fruit" with a corresponding small cost per ton of $\mathrm{CO}_{2}$ abated. Even if the cost per ton abated were to assume an extremely high value of say 100 euro per ton, the median firm in our sample, with carbon emissions of one million tons per year, would only experience a 10 million euro increase in manufacturing costs if it were to reduce emissions by $10 \%$. Furthermore, the impact of any such measures on a firm's gross margin percentage (defined as sales minus cost of goods sold divided by sales) would be offset by any corresponding sales revenue increases. The usual possibilities of a cost pass-through may be enhanced for firms that demonstrate improvements in their carbon footprint in the post-mandate period on account of greater customer loyalty expressing itself in a lower price elasticity of demand.

The combination of cost increases that are likely to be minor in comparison to overall production costs and the potential for improved customer loyalty due to emission reductions leads us to the following hypothesis.

\footnotetext{
${ }^{26}$ By procuring power from outside vendors, a firm will also lower its total Scope 1 plus Scope 2 emissions, if the grid power it purchases is less carbon intensive.
} 
H3: Firms subject to the UK mandate for annual disclosure of GHG emissions exhibit no change in their gross margins compared to firms not subject to the mandate.

Since the firms in our treatment group represent a wide cross-section of UK firms, it is natural to ask whether certain subgroups did achieve carbon emission reductions that differed substantially from the group average. In this context, we differentiate among firms according to the number of installations they own, the percentage of GHG emissions they incur outside of the UK, and the number of sectors they are active in. We use these three variables as the basis of a complexity score, and hypothesize that less complex firms, on average, achieve larger GHG emission reductions following the 2013 mandate.

Our intuitive reasoning underlying the following hypothesis is that less complex firms will, all else equal, find it easier to identify emission reductions that can be achieved across the board. UK-headquartered firms with a larger conglomerate structure could arguably also find it more difficult to incentivize country managers to implement local emission reductions. Finally, such firms may perceive a lesser benefit in terms of their standing with different stakeholder groups due to an overall improvement in GHG emissions as reported by the UK parent company.

H4: Firms subject to the UK mandate with a higher complexity score reduce their GHG emissions by a smaller percentage than their UK counterparts with a lower complexity score.

\section{Research design and data}

\subsection{Empirical test: Hypothesis H1}

We use the following firm-level staggered difference-in-differences approach to estimate the effect of the GHG emission disclosure mandate on actual emissions following the UK Companies Act:

$$
\begin{aligned}
& E=\alpha_{0}+\alpha_{1} \cdot \text { Post }+\alpha_{2} \cdot \text { Post } \cdot \text { Treat }+\sum \text { Control variables } \\
& + \text { Fixed effects for firms }+ \text { Fixed effects for years }+ \text { Industry time trends }+\varepsilon
\end{aligned}
$$

All variables are defined in Table 1 . Our dependent variable $E$ indicates the natural logarithm of $\mathrm{CO}_{2}$-equivalent $\mathrm{GHG}$ emissions at the aggregate level of the firm owning the installation (as illustrated in Fig. 1). Emission data for one firm-year observation are based on emission data on the portfolio of installations owned by the firm in a particular year. ${ }^{27}$

\footnotetext{
$\overline{{ }^{27}}$ We also estimate the model at the level of individual installations. For this test, we adjust all firm-level variables accordingly. For example, instead of aggregate emissions at the firm level, we consider emissions of the individual installation as the dependent variable. In a similar vein, we insert fixed effects at the installation rather than firm level. Since we have no data on the characteristics of individual installations except for emissions and operating activity, we keep the time-variant characteristics of the firm owning the installation as control variables for this regression.
} 
Post is a binary variable indicating periods after the mandate for GHG emission disclosure. Our study is based on observations from the years 2009-2018. The mandate for GHG emission disclosure applies to all fiscal years ending on or after September 30, 2013. If a firm's fiscal year ends before this date, we define the emissions reported for the calendar year 2013 as a pre-treatment observation. If a firm's financial year ends on or after September 30, 2013, we define emissions reported for the calendar year 2013 as a post-treatment observation. As a consequence, the mandate to disclose GHG emissions applies to firms as of 2013 or 2014 (staggered implementation), depending on the respective fiscal year-end date.

Treat is an indicator variable that assumes the value of one if a firm was subject to the mandate and zero otherwise. As the control group, we use firms not subject to the mandate for GHG emission disclosure. Specifically, the control group consists of listed firms headquartered in other EU15 countries. Our primary variable of interest is $\alpha_{2}$. Post - Treat. A significant negative coefficient on $\alpha_{2}$ indicates that, on average, the treated firms achieved an incremental reduction in emissions following the disclosure mandate.

In estimating Eq. (1), we include a set of time-variant control variables at the firm level to account for differences in firm characteristics that might influence a firm's incentives and abilities to reduce emission levels. Specifically, we control for firm size, because larger firms might have a higher willingness and ability to reduce emissions, as they are more visible to the public and might have economies of scope or scale in reducing emissions. We also include asset intensity. Firms with a larger asset base may have to invest in new technologies to reduce carbon emissions, while firms with relatively fewer assets could facilitate emission reductions in the short term through operational changes. Another control variable is the price-to-book ratio, because future growth opportunities may be related to a firm's ability to reduce its carbon emissions. We finally include leverage, to account for outside control by creditors and the financing potential for reducing emissions.

To account for different country-level developments between firms listed in the UK and EU countries, we control for countries' GDP and changes in producer prices as measured by the Producer Price Index. To control for time-specific and firm-specific unobserved heterogeneity, we include firm and year fixed effects for all tests. ${ }^{28}$ Year fixed effects capture annual effects that pertain to all firms, such as changes in gasoline prices. $^{29}$ Finally, we include yearly time trends for the industry in which a firm operates, where we define industries based on the SIC 1 sector classification. ${ }^{30}$ Industry trends capture the industry-specific developments over time, e.g., increasing prices of inputs specific to certain industries.

To reduce the influence of outliers, we winsorize all continuous variables at the 1 st and 99th percentiles. ${ }^{31}$ We draw our inferences based on standard errors that are twoway clustered by country (12 clusters) and year (10 clusters), reflecting that all

\footnotetext{
${ }^{28}$ Since we control for firm fixed effects, the binary variable corresponding to the treatment group firms is absorbed by the fixed effects. This variable is therefore excluded from all tests.

${ }^{29}$ Because of the staggered implementation, we are able to estimate a model including year fixed effects as well as a variable indicating periods after the mandate for GHG emission disclosure (Post).

${ }^{30}$ For the installation-level analysis, we use the NACE Rev. 2 industry classification, as SIC codes are not available at the installation level.

${ }^{31}$ We obtain virtually identical results using no outlier treatment.
} 
Table 1 Definition of variables

\begin{tabular}{|c|c|c|}
\hline Variable & Definition & Data Source \\
\hline \multicolumn{3}{|l|}{ Dependent variables } \\
\hline $\ln$ (Emissions) & $\begin{array}{l}\text { Natural logarithm of yearly emissions in } \\
\text { metric tons of } \mathrm{CO}_{2} \text { eq. }\end{array}$ & EU ETS \\
\hline $\ln ($ Emissions/COGS) & $\begin{array}{l}\text { Natural logarithm of yearly emissions } \\
\text { scaled by COGS. }\end{array}$ & EU ETS, Worldscope \\
\hline $\ln ($ Emissions/Sales) & $\begin{array}{l}\text { Natural logarithm of yearly emissions } \\
\text { scaled by sales. }\end{array}$ & EU ETS, Worldscope \\
\hline Gross Margin & Sales minus COGS scaled by sales. & Worldscope \\
\hline $\ln (C O G S)$ & Natural logarithm of COGS. & Worldscope \\
\hline $\ln ($ Sales $)$ & Natural logarithm of sales. & Worldscope \\
\hline \multicolumn{3}{|l|}{ Experimental variables } \\
\hline Post & $\begin{array}{l}\text { Indicator variable, } 1 \text { : financial years ending } \\
\text { on or after September 30, 2013, 0: otherwise. }\end{array}$ & BvD Orbis \\
\hline Treat & $\begin{array}{l}\text { Indicator variable, 1: UK listed and } \\
\text { incorporated firm affected by the } \\
\text { disclosure mandate, i.e., UK-incorporated } \\
\text { company whose equity capital is either listed } \\
\text { on the Main Market of the London Stock } \\
\text { Exchange, an exchange in a European } \\
\text { Economic Area state, the New York Stock } \\
\text { Exchange or Nasdaq, } 0 \text { : otherwise. }\end{array}$ & BvD Orbis \\
\hline Complexity & $\begin{array}{l}\text { First principal component of the following } \\
\text { variables measured using values prior } \\
\text { to treatment: (1) number of installations } \\
\text { belonging to a firm, (2) percentage of } \\
\text { foreign emissions of all installations } \\
\text { belonging to a firm, and (3) number of } \\
\text { different sectors of all installations } \\
\text { belonging to a firm. }\end{array}$ & EU ETS \\
\hline \multicolumn{3}{|l|}{ Control variables } \\
\hline Size & Natural logarithm of a firm's market value in thousand USD. & Worldscope \\
\hline Leverage & Total debt divided by total assets. & Worldscope \\
\hline Asset Intensity & $\begin{array}{l}\text { Property, plant, and equipment divided } \\
\text { by total assets. }\end{array}$ & Worldscope \\
\hline Price-to-Book & Market value to book value. & Worldscope \\
\hline$G D P$ & $\begin{array}{l}\text { Natural logarithm of a country's gross } \\
\text { domestic product in million euro. }\end{array}$ & Eurostat \\
\hline Input prices & $\begin{array}{l}\text { Annual growth rate of the country-level } \\
\text { producer price index. }\end{array}$ & Eurostat \\
\hline
\end{tabular}

This table defines all variables used in this study 
installations of a UK-listed and incorporated firm are subject to the mandate, independent of the actual geographic location or industry classification of an installation. ${ }^{32}$

\subsection{Empirical test: Hypothesis $\mathrm{H} 2$}

To estimate the effects of the GHG emission disclosure mandate on carbon intensity, we run the following regression at the firm level:

$$
\begin{aligned}
& C I=\beta_{0}+\beta_{1} \cdot \text { Post }+\beta_{2} \cdot \text { Post } \cdot \text { Treat }+\sum \text { Control variables } \\
& + \text { Fixed effects for firms }+ \text { Fixed effects for years }+ \text { Industry time trends }+\varepsilon
\end{aligned}
$$

Table 1 again lists the formal definitions of all variables. The dependent variable measures carbon intensity, which is defined as the natural logarithm of emissions to the cost of goods sold (COGS). Thus, carbon intensity expresses the tons of $\mathrm{CO}_{2}$ equivalent per euro of goods that the firm sold in a particular year. As before, we employ a staggered difference-in-differences approach with the same regressors as in Eq. (1). In a variant of Eq. (2), we use the natural logarithm of emissions to sales as our alternative carbon intensity measure. ${ }^{33} \mathrm{We}$ estimate our regressions for $\mathrm{H} 2$ only at the firm level because production costs and sales data are not available at the installation level.

\subsection{Empirical test: Hypothesis H3}

To test the impact of the disclosure mandate on gross margins, we estimate the following regression at the firm level:

$$
\begin{aligned}
& \text { GM }=\gamma_{0}+\gamma_{1} \cdot \text { Post }+\gamma_{2} \cdot \text { Post } \cdot \text { Treat }+\sum \text { Control variables } \\
& + \text { Fixed effects for firms }+ \text { Fixed effects for years }+ \text { Industry time trends }+\varepsilon
\end{aligned}
$$

Here, GM represents the gross margin, defined as sales minus cost of goods sold, scaled by sales. ${ }^{34}$ Again, we employ a staggered difference-in-differences approach. Post and Treat are defined as before. The variable of interest is Post $\cdot$ Treat. According to H3, we expect no significant coefficient on Post $\cdot$ Treat. All control variables and fixed effect variables are as explained above.

\subsection{Empirical test: Hypothesis H4}

To test how a firm's complexity influences the impact of the disclosure mandate on GHG emissions, we estimate the following regression at the firm level:

\footnotetext{
$\overline{32}$ Results are robust using one-way clustering at the country-year level (120 clusters) to account for a potential influence of a lower number of clusters when using two-way clustering.

${ }^{33}$ Our approach here reflects that we only have access to information regarding the composite measure of sales or cost of goods sold, but not the quantities produced or sold of individual products.

${ }^{34}$ We find qualitatively unchanged results for net profits, defined as sales minus cost of goods sold minus SG\&A expense scaled by sales.
} 
$E=\delta_{0}+\delta_{1} \cdot$ Post $+\delta_{2} \cdot$ Post $\cdot$ Treat $+\delta_{3} \cdot$ Post $\cdot$ Treat $\cdot$ Complexity

$+\delta_{4} \cdot$ Post $\cdot$ Complexity $+\sum$ Control variables + Fixed effects for firms

+ Fixed effects for years + Industry time trends $+\varepsilon$

Here, Complexity is an aggregate score that relies on information regarding the firms' installations, as recorded in the EU ETS registry data. Specifically, we compute the complexity score by conducting a principal component analysis using the following three variables: the firm's total number of installations, percentage of emissions abroad, and the number of sectors in which it has active installations. We rely on the first principal component of the component analysis and measure the score using pretreatment period values. ${ }^{35}$ A higher score indicates that a firm has a more complex operating structure. To test H4, we interact the DiD coefficient Post $\cdot$ Treat with the complexity score.

\subsection{Data}

Table 2 delineates the sample selection process. Our starting sample comprises all EU ETS installations with emission data for the period 2009-2018 (14,003 installations). We first assign all installations to their ultimate owner. Figure 1 illustrates the assignment of installations to firms. In a first step, we exclude all installations where data on the ultimate owner is missing, because in these cases we are not able to assign installations to the treatment or control group. The link between the installation and the ultimate corporate owner is established by the Ownership Links and Enhanced EUTL Dataset Project (OLP). ${ }^{36}$ The OLP provides the name and Bureau-van-Dijk identification number (BvD-ID) of an installation's parent company. Next, we drop installations owned by firms with missing information on the fiscal year end in the BvD Orbis database. These steps lead to a sample of 6,327 installations owned by 1,994 unique firms.

Next, we limit our sample to installations owned by firms from EU15 countries. As we only observe emissions regulated under the EU ETS, we focus on European firms for all tests. This step results in a sample of 5,196 installations owned by 1,486 unique firms.

We also limit the sample to listed firms, because disclosure and emission reduction effects might differ between listed and unlisted firms. By restricting our sample to listed firms, we ensure the comparability of treatment and control firms. ${ }^{37}$ This step leads to a sample of 2,274 installations owned by 197 unique firms. ${ }^{38}$

\footnotetext{
$\overline{35}$ The eigenvalue of the first principal component is 1.64. Eigenvalues of all remaining principal components are below 1 .

${ }^{36}$ Data and a technical note describing the mapping from installations to ultimate owners is available at https:// cadmus.eui.eu/handle/1814/64596. Note that the mapping in the OLP dataset was conducted in 2013, based on ownership information for 2005-2007. As it affected UK and non-UK companies, any potential impact its publication may have had on emissions is captured by year fixed effects.

${ }^{37}$ In sensitivity analyses, we perform a matched sample approach to account for differences in emissions between firms and find virtually unchanged results.

${ }^{38}$ We note that the number of listed firms in the EU ETS is rather small compared to the total number of listed firms in Europe. This is because a relatively small number of manufacturing firms account for a large share of total emissions (CDP 2017). Thus, a smaller sample size does not impair the external validity of our findings.
} 
We further exclude firms from countries with other confounding regulations. ${ }^{39}$ During our sample period, only Ireland implemented an emission-related regulation (InsideIreland.ie 2009). We also exclude installations for which the ultimate owner changed during the sample period because, otherwise, the assignment of the treatment group might be biased. These two restrictions lead to a sample of 2,212 installations owned by 193 unique firms.

Our sample also excludes installations in the energy supply sector based on the NACE Rev.2 sector code 35. This exclusion reflects that, for this sector, the UK government implemented an additional policy to increase the EU ETS allowance price in 2013 (the so-called "Carbon Price Floor" [CPF]). The CPF applies to electricity producers (Hirst 2018) and provides an additional emission charge beyond the EU ETS. Thus, the inclusion of these installations would likely lead to results overstating the impact of the disclosure mandate. ${ }^{40}$ This restriction leads to a sample of 1,224 installations owned by 175 unique firms.

Next, we exclude installations in case of maintenance as well as temporary or permanent shutdowns because these emission reductions are likely unrelated to the mandate to disclose GHG emissions. ${ }^{41}$ To identify maintenance, we exclude installations if their minimum emission level over the sample period is less than $1 \%$ of their maximal emission level. We identify temporary or permanent shutdowns based on incomplete emission data over time. ${ }^{42}$ This step leads to a sample of 754 installations owned by 140 unique firms.

To estimate disclosure effects at the firm level, we next aggregate installation-level emissions to the firm level. At the firm level, we exclude firm-years with missing data for estimating our specified regression models. Firm-level accounting data are taken from Worldscope Datastream. This leads to a sample of 1,268 firm-years from 130 unique firms. Finally, we exclude firms without at least one observation prior to and after the passage of the Companies Act, to ensure applicability of a difference-indifferences approach. This step leads to a final firm-level sample of 1,257 firm years from 127 unique firms. The final installation-level sample consists of 7,267 installation years from 729 unique installations. In this sample, 24 firms belong to the treatment group, and 104 firms belong to the control group. An average sample firm operates 5.74 unique installations.

Table 3 presents the sample composition by country. All our treatment group firms are incorporated in the UK, whereas most of our control group firms are incorporated in France, Germany, Spain, and Sweden.

\footnotetext{
${ }^{39}$ We focus on potentially confounding regulations on non-financial disclosure because they are the most likely to bias our results. UK and other major countries (France, Germany, Italy, Spain) implemented the EU Directive 2013/34/EU into national law in 2015. However, this directive most significantly affected small companies, and the changes primarily related to financial disclosure. An adaptation of the directive to require non-financial disclosure (EU Directive 2014/95/EU) was only relevant for fiscal years 2017 and later. Our results are robust to a shorter sample period.

${ }^{40}$ We find virtually unchanged results if we keep energy sector installations in the sample.

${ }^{41}$ As an example, Lynemouth Power Station reported 2,717,964 $\mathrm{tCO}_{2}$ eq in 2014; 1,287,305 $\mathrm{tCO}_{2}$ eq in 2015; and $1,059 \mathrm{tCO}_{2}$ eq in 2016 .

${ }^{42}$ We find virtually unchanged results if we use a lower threshold $(0.5 \%)$ or a higher threshold (5\%). If we keep all installations independent of (temporary) shutdowns, we obtain higher point estimates and hence estimate a lower bound of the treatment effect.
} 
Table 2 Sample selection

\begin{tabular}{|c|c|c|c|c|}
\hline \multirow[t]{2}{*}{ Initial sample } & \multicolumn{2}{|c|}{ Installation level } & \multicolumn{2}{|c|}{ Firm level } \\
\hline & $\begin{array}{l}\text { Installation } \\
\text { years }\end{array}$ & $\begin{array}{l}\text { Unique } \\
\text { installations }\end{array}$ & $\begin{array}{l}\text { Firm } \\
\text { years }\end{array}$ & $\begin{array}{l}\text { Unique } \\
\text { firms }\end{array}$ \\
\hline $\begin{array}{l}\text { All installations listed in the EU ETS with non-missing emission } \\
\text { data. Sample period 2009-2018 }\end{array}$ & 109,029 & 14,003 & & \\
\hline \multicolumn{5}{|l|}{ Installation-level exclusion of } \\
\hline $\begin{array}{l}\text { installations without known ultimate owner or date of fiscal } \\
\text { year end }\end{array}$ & 50,268 & 6,327 & & 1,994 \\
\hline installations owned by non-EU firms & 41,419 & 5,196 & & 1,486 \\
\hline installations owned by unlisted firms & 18,861 & 2,274 & & 197 \\
\hline $\begin{array}{l}\text { installations affected by confounding regulations or } \\
\text { ownership changes }\end{array}$ & 18,409 & 2,212 & & 193 \\
\hline energy sector installations & 10,018 & 1,224 & & 175 \\
\hline $\begin{array}{l}\text { virtually closed installations (i.e., maintenance and } \\
\text { temporary or permanent shutdown) }\end{array}$ & 7,540 & 754 & 1,399 & 140 \\
\hline \multicolumn{5}{|l|}{ Firm-level exclusion of } \\
\hline missing firm-level variables for estimating Eqs. (1)-(4) & 7,293 & 735 & 1,268 & 130 \\
\hline $\begin{array}{l}\text { firms without at least one observation prior to and after the } \\
\text { implementation of the Companies Act }\end{array}$ & 7,267 & 729 & 1,257 & 127 \\
\hline Final sample for firm-level regression analyses & & & 1,257 & 127 \\
\hline Final sample for installation-level regression analyses & 7,267 & 729 & & \\
\hline
\end{tabular}

This table delineates the sample selection for estimating the influence of the disclosure mandate on firms' GHG emission levels and operating performance

Given the exclusion of energy sector installations, the firms in our sample are mostly manufacturing firms: 548 firm-year observations belong to the SIC industry 2 (i.e. SIC 2000-2999), and 366 belong to the SIC industry 3 (i.e. SIC 3000-3999).

Table 4 reports descriptive statistics (Panel A) and correlations (Panel B) for our final sample. The average treatment (control) group firm in our sample produces yearly emissions of $807,641(1,280,441) \mathrm{tCO}_{2}$ eq. We observe that treated firms emit less GHG, on average, and have a lower carbon intensity, a higher COGS, higher sales, and a higher gross margin than control firms. Due to a skewed distribution, we use log-transformed emissions, carbon intensity, COGS, and sales in our regression analyses. We also find that firms in the treatment group are larger and more highly leveraged and have higher asset intensity and price to book ratio compared to control group firms. With regard to the Pearson and Spearman correlations, we do not observe high correlations between the continuous control variables. 
Table 3 Sample composition

\begin{tabular}{llll}
\hline & Control group & Treatment group & Total \\
\hline Austria & 40 & 0 & 40 \\
Belgium & 60 & 0 & 60 \\
Germany & 216 & 0 & 216 \\
Denmark & 30 & 0 & 30 \\
Spain & 147 & 0 & 147 \\
Finland & 80 & 0 & 80 \\
France & 238 & 0 & 238 \\
United Kingdom & 0 & 237 & 237 \\
Luxembourg & 10 & 0 & 10 \\
The Netherlands & 50 & 0 & 50 \\
Portugal & 39 & 0 & 39 \\
Sweden & 110 & 0 & 110 \\
Total & 1,020 & 237 & 1,257 \\
\hline
\end{tabular}

This table presents the geographic distribution of sample firms. Treatment group firms are listed and incorporated in the United Kingdom. Control group firms are listed and incorporated in other EU15 states

\section{Results}

\subsection{Impact of the 2013 act on GHG emissions and carbon intensity}

Table 5 reports our findings regarding the impact of the GHG disclosure mandate on subsequent GHG emissions. We also test the impact of the mandate on carbon intensity using two alternative definitions: the ratio of emissions to COGS, and the ratio of emissions to sales. By taking logarithms, we can interpret a transformed value of the corresponding coefficients as additive percentage changes.

Columns (I) and (II) in Table 5 present results of our estimations using installationlevel emission data. While our main interest is at the firm level, the installation-level estimates establish a baseline result that allows us to assess possible effects of aggregating installation-level data to the firm level. Columns (I) and (II) present the findings without and with firm-level control variables, respectively. In all specifications, we use installation and year fixed effects and industry time trends.

In column (I) of Table 5 the coefficient on the variable of interest Post $\cdot$ Treatment is significantly negative $(\mathrm{p}:<0.05)$. This result is also sizable in economic terms, as affected firms on average decreased their GHG emissions by about $8 \%$, compared to companies not affected by the act. The $8 \%$ estimate reflects that $1-\exp (-0.082)=$ 0.078. Controlling for differences in firm characteristics (column (II)) leads to a virtually unchanged estimate of -0.082 . We note that the high adjusted $\mathrm{R}^{2}$ is due to the stringent fixed effects specification, which absorbs installation-specific and yearspecific unobservable heterogeneity as well as industry trends. The installation-level results provide evidence for $\mathrm{H} 1$ that emissions of the treated firms decreased compared to installations owned by firms in the control group. 


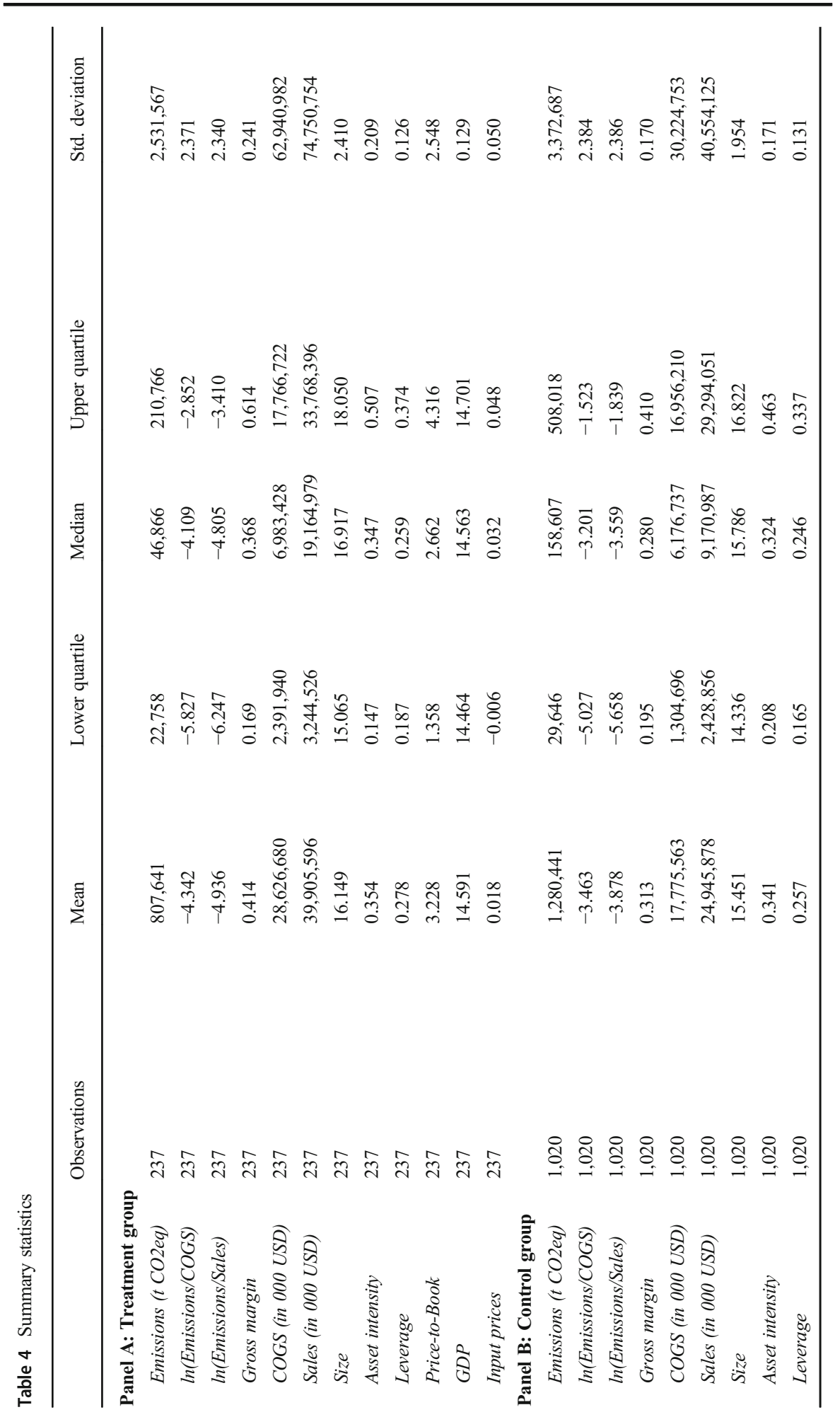




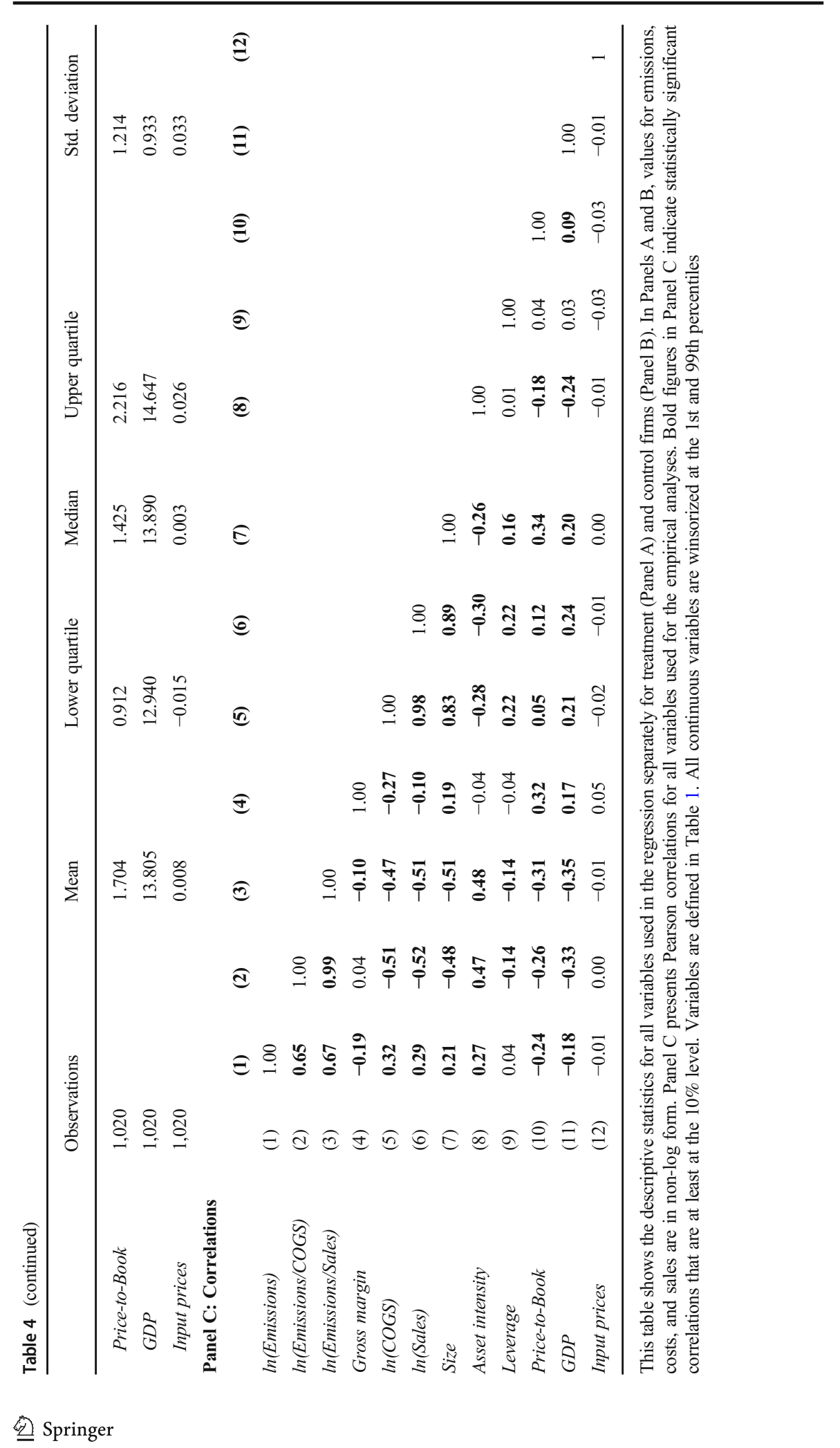




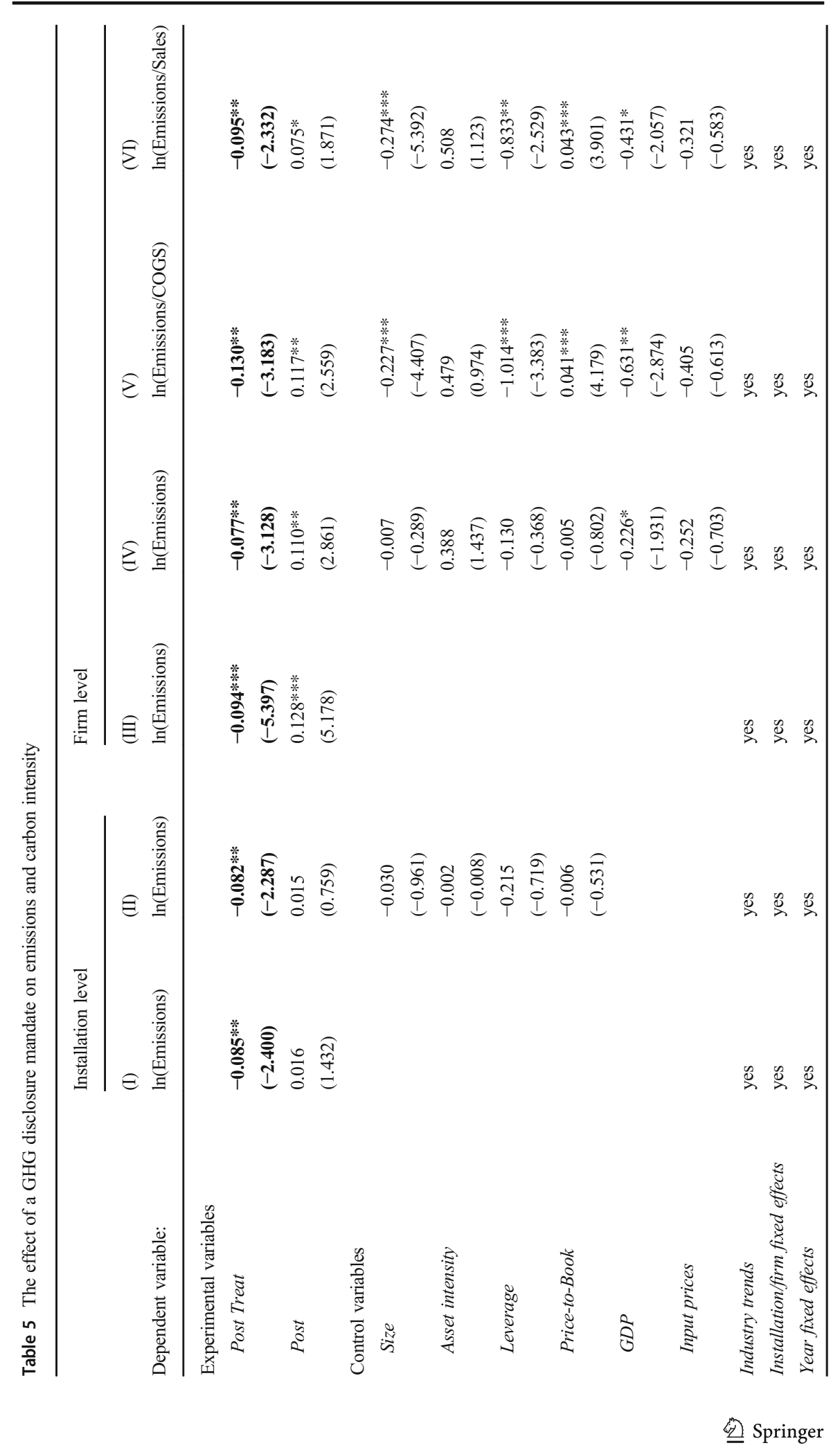




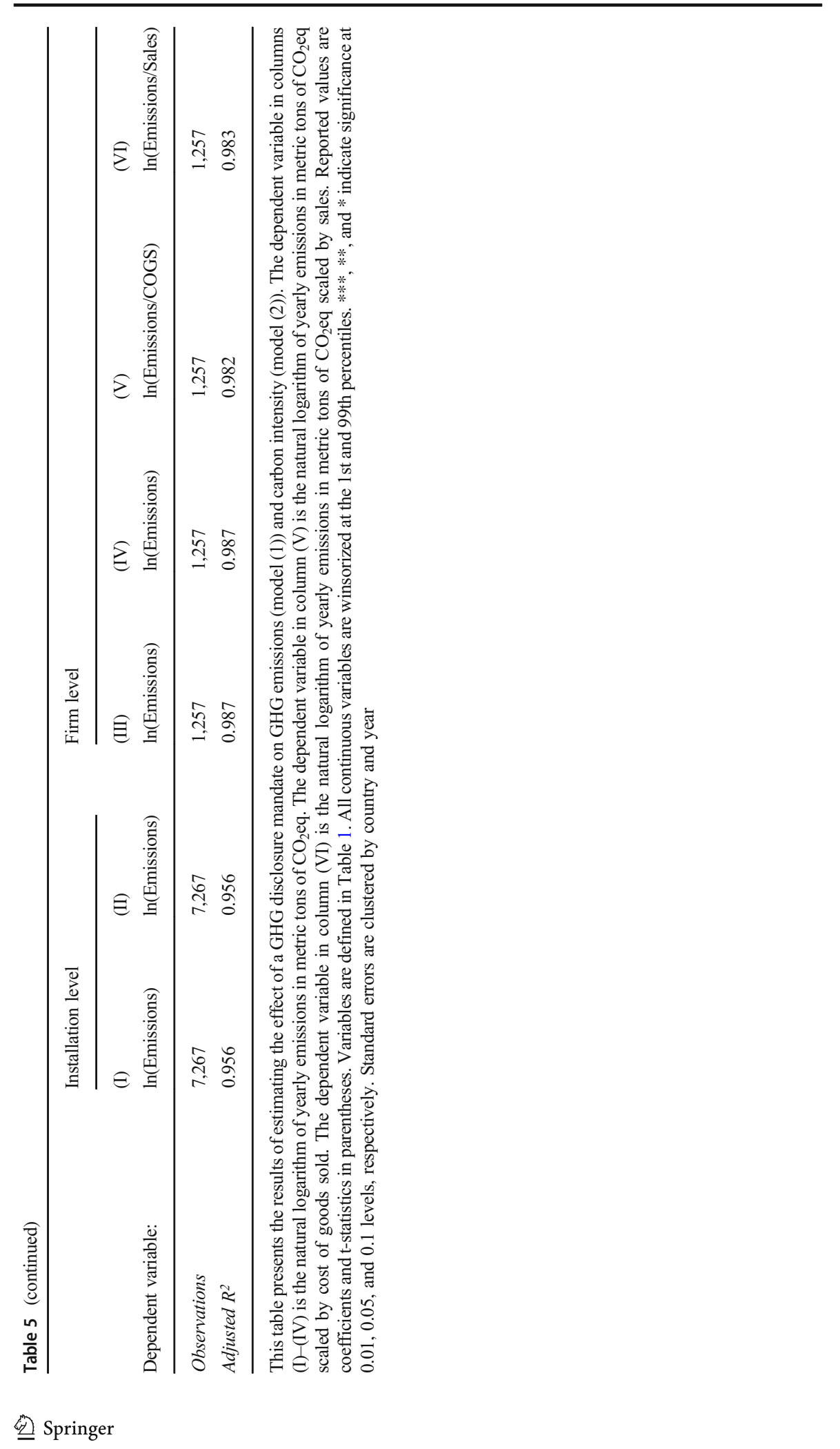


Columns (III) and (IV) in Table 5 present results analogous to those in columns (I) and (II), but at the firm level. These and all remaining firm-level regressions control for unobserved heterogeneity by including year and owner-specific fixed effects. We also account for industry-level trends at the one-digit SIC level. Column (III) reports estimates without further firm- or country-level controls. We again find a negative and significant coefficient estimate on Post $\cdot$ Treat (p: $<0.01$ ), indicating a reduction in GHG emissions for treated firms by about $9 \%$. This reduction is comparable to the emission reduction of about $8 \%$ measured using installation-level emission data (column (I)), suggesting that the reduction in emissions occurs fairly evenly across installations owned by each firm. In the richer specification including further covariates (column IV), we control for the same firm-level covariates as in column (II) as well as for country-level control variables. Column (IV) corroborates the magnitude of the emission reduction obtained in the simpler model. It reports a similar estimated effect, about $8 \%$ ( $\mathrm{p}:<0.05$ ), when controlling for the firm-level variables: size, the ratio of fixed assets to total assets, leverage, and price-to-book value (PTB). The additional controls $\ln (\mathrm{GDP})$ and input prices account for potential differences in aggregate demand and cost developments, respectively. The analysis of firm-level emissions thus also supports hypothesis H1.

In the final set of regressions shown in Table 5, we estimate the effect of the act on firm-level carbon intensity. This dependent variable, defined as either emissions divided by COGS or emissions divided by sales, ensures that any observed emission reductions are not merely a consequence of reductions in production volume. Columns (V) and (VI) report the estimates when including all covariates. The findings are similar to those for $\ln$ (emissions), with estimated reductions in carbon intensity of about $13 \%$ (p: <0.05) when using COGS as the denominator and of about $10 \%(\mathrm{p}:<0.05)$ when using sales as a denominator. These results indicate that the emission reductions were not mainly driven by a decline in output or capacity utilization. ${ }^{43}$

The main assumption underlying the difference-in-differences approach is a common trend between treatment and control group firms (Roberts and Whited 2013). To examine whether a common pre-treatment trend exists for emissions and carbon intensities, we follow common approaches in the existing literature (Bertrand and Mullainathan 2003; Serfling 2016). Specifically, we replace the interaction terms Post - Treatment with separate interaction terms for each period relative to the implementation of the GHG mandate in 2013. We adjust time periods to reflect the staggered nature of the treatment. When estimating the model, insignificant pre-treatment coefficients close to zero indicate the validity of a common pre-treatment trend.

In our tests of parallel trends we focus on firm-level emissions and emissionintensity. ${ }^{44}$ Fig. 2 shows the results for firm-level emissions. Values on the y-axis show point estimates and $90 \%$ confidence intervals. Values on the $\mathrm{x}$-axis refer to the number of years removed from the start of the post-treatment period. The benchmark period is $t=-1$, i.e., the last pre-treatment year. Due to the staggered nature of the treatment, $\mathrm{t}=-1$ is 2012 for many installations, and 2013 for others. Each point estimate shown in Fig. 2 therefore captures the difference in the emission levels

\footnotetext{
${ }^{43}$ Our results on the emission reductions (H1) are robust to controlling for COGS and sales in columns (III) and (IV) in Table 5, instead of using these variables as denominators of emissions, as in columns (V) and (VI). ${ }^{44}$ We observe parallel trends during the pre-treatment period also for installation-level emissions.
} 
between the treatment and control groups relative to $t=-1$. The pre-treatment period consists of the periods $t<=-4$ to $t=-1$, while periods $t=0$ to $t>=4$ constitute the post-treatment period. We aggregate the coefficients for the first and last periods depicted, also due to the staggered treatment. Accordingly, the $\mathrm{t}<=-4$ value represents the average of the coefficient estimates for the interactions between each Treat variable and year dummies for periods four or more years prior to treatment. Analogously, the $\mathrm{t}>=4$ value is the average of the estimates for the interactions between Treat and year dummies for periods four or more years after treatment.

Regarding firm-level emissions, Fig. 2 indicates a difference in pre-treatment and post-treatment coefficients. While treated firms have somewhat higher pretreatment emissions than the control group four years prior to the mandate, this difference is fairly stable and close to zero during the three-year pre-treatment period. Point estimates are not significantly different from zero in any year from $\mathrm{t}>-4$ to $\mathrm{t}=-1 .{ }^{45}$ Based on these results, we do not find any violation of the common trends assumption for firm-level emissions. The estimates for the period $t=0$ to $t>=4$ show the evolution of the treatment effect over time. We observe that emissions in the treatment group decrease immediately after the start of the post-treatment period. The treated firms decrease their emissions and maintain their reductions for the first two years until $t=1$. Thereafter, emission levels converge again between the two groups.

A comparison with the findings in Grewal (2021) may be instructive. First, while Grewal's (2021) emission measure consists of total Scope 1 and Scope 2 emissions, we focus solely on Scope 1 emissions. Second, while our estimated average emission reduction is consistent with the main finding in Grewal (2021), the results from our event study design suggest that the effect on emissions is transitory. The findings in the two studies are therefore complementary, as both the samples and the emission outcome variables differ.

Figure 3 shows the results for carbon intensity. A similar picture emerges as in Fig. 2, irrespective of whether we define carbon intensity as emissions divided by COGS (Fig. 3, Panel a) or as emissions divided by sales (Fig. 3, Panel b). Point estimates are not significantly different from zero in any year from $\mathrm{t}>-4$ to $\mathrm{t}=-1$, thus supporting the common trend assumption. Again, we observe a clear treatment effect, which manifests itself at the beginning of the post-treatment period. As with emissions, coefficients immediately after the start of the post-treatment period are negative and marginally significant, while point estimates converge to zero in later years.

\footnotetext{
${ }^{45}$ As shown in Figs. 2 and 3, we cannot rule out a violation of the parallel trend assumption further than four years ahead of the mandate. Using a shorter pre-treatment period beginning at $\mathrm{t}=-3$ instead yields more stable trends but lower treatment effects, i.e., ranging between -0.108 and -0.054 . Yet, these lower estimates are attributable to our strict and conservative sample composition. This composition already provides a lower bound of the effect, because we exclude installations that are subject to temporary or permanent shutdowns. If we instead attribute temporary shutdowns to the disclosure mandate, i.e., opt for a less strict approach, we find more pronounced negative effects even for the shortened-time series (point estimates ranging between -0.186 and -0.158 ), as well as for the full sample (point estimates ranging between -0.212 and -0.185 ). If we attribute temporary as well as permanent shutdowns to the disclosure mandate, i.e., opt for the least strict approach, we find negative effects for the shortened-time series (point estimates ranging between -0.274 and -0.247 ) as well as for the full time-series (point estimates ranging between -0.302 and -0.275 ).
} 


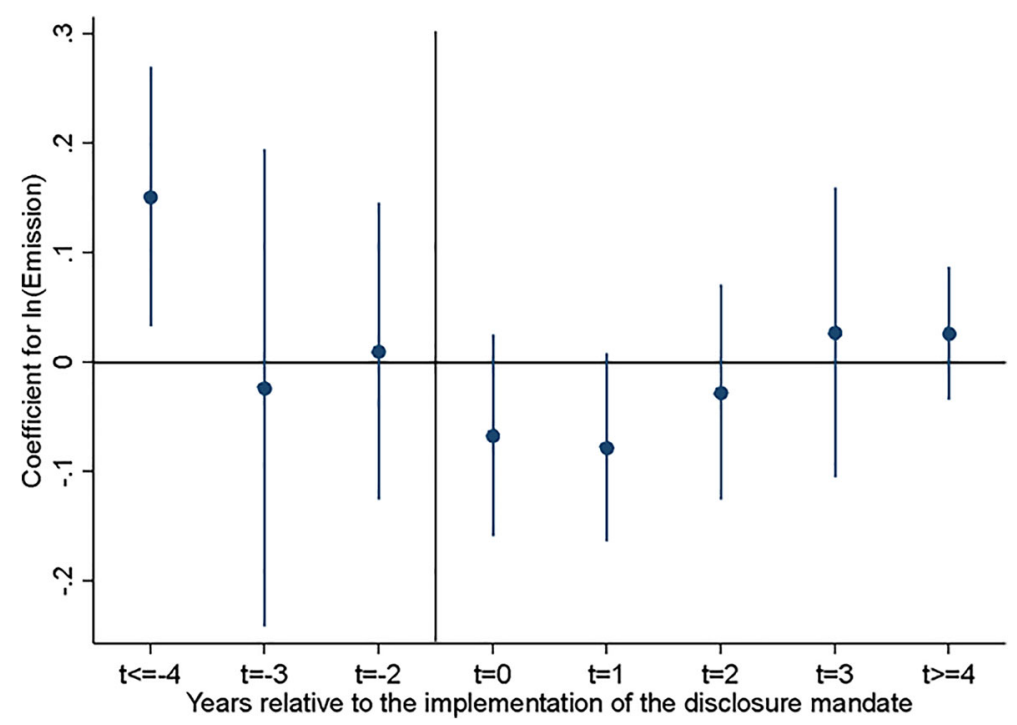

Fig. 2 Emission levels around the disclosure mandate. This figure shows the change in verified GHG emissions surrounding the disclosure mandate. Values on the y-axis show differences in the natural logarithm of emissions of treated and control group firms and $90 \%$ confidence intervals. To obtain these estimates, we replicate model (1) but replace Post - Treat with separate interaction terms for each individual period surrounding the mandate. To account for the staggered implementation of the disclosure mandate, we adjust time periods using relative time periods. Values on the $\mathrm{x}$-axis indicate periods relative to the first-time application of the mandate $(t=0)$. For firms with fiscal year end after September 30, 2013, $t=0$ refers to the year 2013. For firms with fiscal year end before September 30, 2013, $t=0$ refers to the year 2014. Periods $\mathrm{t}=-2, \mathrm{t}=-3$, and $\mathrm{t}<=-4$ are prior to the first-time application of the disclosure mandate. Periods $\mathrm{t}=0, \mathrm{t}=+1$, and $t>=2$ are on or after the first-time application of the disclosure mandate. We use the last year prior to the first-time application $(\mathrm{t}=-1)$ as the benchmark period

\subsection{Effects on financial operating performance}

Our next set of tests addresses the effects of the mandate on the financial operating performance. Table 6 present the results. In column (I), we show the results without including further control variables. We find a significantly negative treatment effect on the firms' gross margins. Column (II) of Table 6 shows the results when controlling for firm size, asset intensity, leverage, and PTB, as well as for a country's GDP and changes in input prices - the point estimate becomes statistically insignificant. This result shows that the gross margins of disclosing firms following the 2013 mandate are not statistically different from the margins of our control group of non-disclosing firms, providing support for hypothesis $\mathrm{H} 3$.

To further explore our findings on $\mathrm{H} 3$, we investigate the individual components of the gross margin, i.e., production costs and sales. The unaffected gross margins we documented before do not rule out any increases in production costs. Stable gross margins could likewise be consistent with a simultaneous increase in both costs and sales.

We first estimate the treatment effect of the UK mandate on changes in production costs and rerun our DiD estimation using the logarithm of costs of goods sold as the dependent variable. Column (III) in Table 6 presents the results without further control variables. The findings suggest that firms subject to the mandate incur, on average, a 


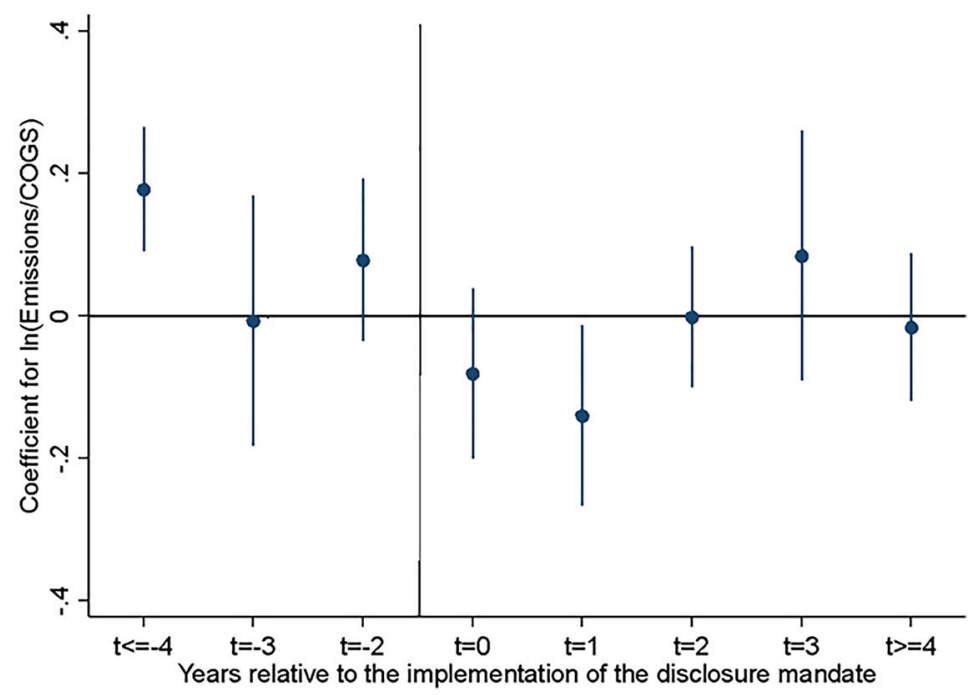

$B$

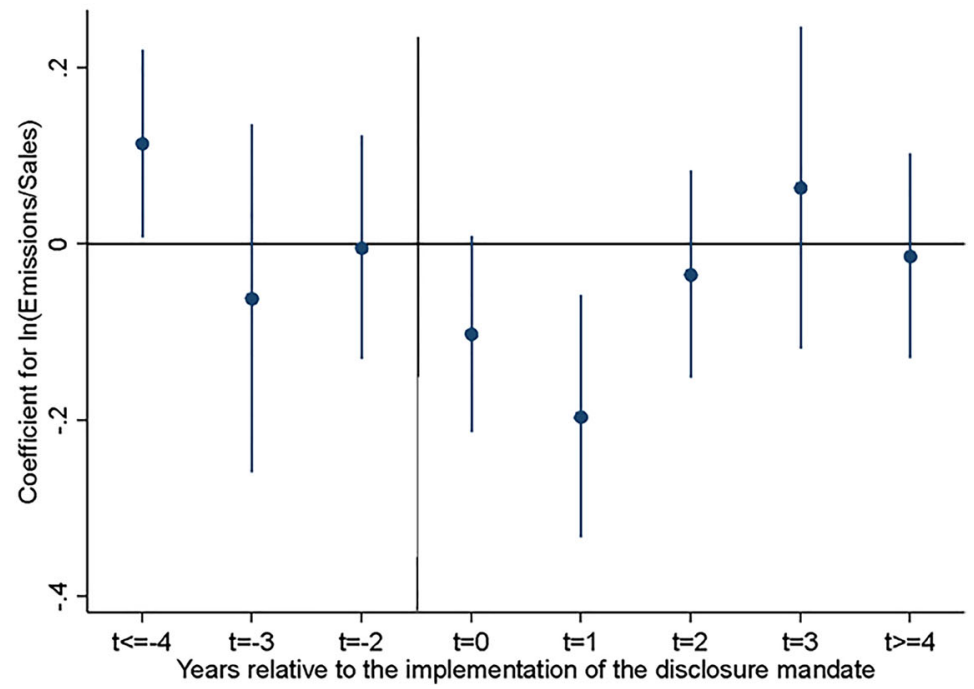

Fig. 3 Carbon intensity around the disclosure mandate. Panel A: $\ln ($ Emissions/COGS). Panel B: $\ln ($ Emissions/Sales). This figure shows the change in carbon intensity surrounding the disclosure mandate. Panel A shows carbon intensity defined as $\ln ($ Emissions/COGS). Panel B shows carbon intensity defined as $\ln ($ Emissions/Sales $)$. Values on the y-axis show differences in carbon intensity reductions of treated and control group firms and $90 \%$ confidence intervals. To obtain these estimates, we replicate model (2) but replace Post . Treat with separate interaction terms for each individual year surrounding the mandate. To account for the staggered implementation of the disclosure mandate, we adjust time periods using relative time periods. Values on the $\mathrm{x}$-axis indicate periods relative to the first-time application of the disclosure mandate $(t=0)$. For firms with fiscal year end after September 30, 2013, $t=0$ refers to the year 2013. For firms with fiscal year end before September 30, 2013, $t=0$ refers to the year 2014. Periods $t=-2, t=-3$, and $t<=-4$ are prior to the first-time application of the disclosure mandate. Periods $t=0, t=+1$, and $t>=2$ are on or after the first-time application of the disclosure mandate. We use the last year prior to the first-time application $(t=-1)$ as the benchmark period 
statistically significant increase in production costs of about $10 \%(\mathrm{p}:<0.1)$. Based on this simple specification, the estimates suggest that emission reductions have been costly to firms. However, after adding the same control variables used in the other tests, the point estimate is reduced in magnitude and becomes statistically insignificant, as shown in column (IV) of Table 6. Thus, when taking account of the different firm and country characteristics, our results imply that firms were indeed able to find low-cost options when reducing their GHG emissions. In untabulated regressions, we confirm this result in a corresponding test when using capital expenditures (CAPEX) as the dependent variable instead of costs of goods sold. Hence, the observed emission reductions cannot be related to an increase in capital expenditures for, e.g., more energy-efficient machinery and appliances, either.

Table 6 The effect of a GHG disclosure mandate on financial operating performance

\begin{tabular}{|c|c|c|c|c|c|c|}
\hline Dependent variable: & $\begin{array}{l}\text { (I) } \\
\text { Gross margin }\end{array}$ & $\begin{array}{l}\text { (II) } \\
\text { Gross margin }\end{array}$ & $\begin{array}{l}\text { (III) } \\
\ln (\mathrm{COGS})\end{array}$ & $\begin{array}{l}\text { (IV) } \\
\ln (\mathrm{COGS})\end{array}$ & $\begin{array}{l}\text { (V) } \\
\ln \text { (Sales) }\end{array}$ & $\begin{array}{l}(\mathrm{VI}) \\
\ln (\text { Sales })\end{array}$ \\
\hline \multicolumn{7}{|l|}{ Experimental variables } \\
\hline Post Treatment & $\begin{array}{l}-0.030 * * * \\
(-3.623)\end{array}$ & $\begin{array}{l}-0.015 \\
(-1.032)\end{array}$ & $\begin{array}{l}0.107^{*} \\
(2.255)\end{array}$ & $\begin{array}{l}0.067 \\
(1.531)\end{array}$ & $\begin{array}{l}0.046 \\
(1.075)\end{array}$ & $\begin{array}{l}0.025 \\
(0.580)\end{array}$ \\
\hline Post & $\begin{array}{l}0.024 * * * \\
(3.468)\end{array}$ & $\begin{array}{l}0.018 * * \\
(2.388)\end{array}$ & $\begin{array}{l}-0.086 * * \\
(-2.516)\end{array}$ & $\begin{array}{l}-0.007 \\
(-0.257)\end{array}$ & $\begin{array}{l}-0.040 \\
(-1.647)\end{array}$ & $\begin{array}{l}0.034 \\
(1.335)\end{array}$ \\
\hline \multicolumn{7}{|l|}{ Control variables } \\
\hline Size & & $\begin{array}{l}0.022 * * * \\
(3.349)\end{array}$ & & $\begin{array}{l}0.200^{* * *} \\
(3.923)\end{array}$ & & $\begin{array}{l}0.248 * * * \\
(4.998)\end{array}$ \\
\hline Asset intensity & & $\begin{array}{l}0.008 \\
(0.150)\end{array}$ & & $\begin{array}{l}-0.164 \\
(-0.455)\end{array}$ & & $\begin{array}{l}-0.141 \\
(-0.441)\end{array}$ \\
\hline Leverage & & $\begin{array}{l}-0.071 \\
(-1.202)\end{array}$ & & $\begin{array}{l}0.846^{* * * *} \\
(4.787)\end{array}$ & & $\begin{array}{l}0.677 * * * \\
(4.996)\end{array}$ \\
\hline Price-to-Book & & $\begin{array}{l}-0.001 \\
(-0.629)\end{array}$ & & $\begin{array}{l}-0.044 * * * \\
(-3.311)\end{array}$ & & $\begin{array}{l}-0.047 * * * \\
(-3.372)\end{array}$ \\
\hline$G D P$ & & $\begin{array}{l}-0.150 * \\
(-1.932)\end{array}$ & & $\begin{array}{l}0.409^{*} \\
(2.151)\end{array}$ & & $\begin{array}{l}0.253 \\
(1.734)\end{array}$ \\
\hline Input prices & & $\begin{array}{l}-0.091 \\
(-1.174)\end{array}$ & & $\begin{array}{l}0.157 \\
(0.358)\end{array}$ & & $\begin{array}{l}0.088 \\
(0.214)\end{array}$ \\
\hline Industry trends & yes & yes & yes & yes & yes & yes \\
\hline Installation/firm fixed effects & yes & yes & yes & yes & yes & yes \\
\hline Year fixed effects & yes & yes & yes & yes & yes & yes \\
\hline Observations & 1,257 & 1,257 & 1,257 & 1,257 & 1,257 & 1,257 \\
\hline Adjusted $R^{2}$ & 0.902 & 0.905 & 0.986 & 0.988 & 0.988 & 0.990 \\
\hline
\end{tabular}

This table presents the results of estimating the effect of a GHG disclosure mandate on financial operating performance (Eq. (3)). The dependent variable in columns (I) and (II) is the yearly gross margin. The dependent variable in columns (III) and (IV) is the natural logarithm of yearly COGS. The dependent variable in columns (V) and (VI) is the natural logarithm of yearly sales. Reported values are coefficients and t-statistics in parentheses. Variables are defined in Table 1. All continuous variables are winsorized at the 1st and 99th percentiles. $* * *, * *$, and $*$ indicate significance at $0.01,0.05$, and 0.1 levels, respectively. Standard errors are clustered by country and year 
We also run our estimation using the logarithm of sales as the dependent variable. With stable gross margins and statistically unchanged production costs, we expect to see no changes in sales. Columns (V) and (VI) of Table 6 show the results. The findings without and with covariates validate this conjecture.

Finally, we examine the parallel pre-treatment trends in both COGS and sales for UK and EU firms. For instance, we could fail to identify cost effects for the UKdisclosing firms, if EU firms in our control group experienced an upward trend in costs for other reasons. In Fig. 4, we plot the common trend graphs for COGS and sales. As before, we compute the differences for UK and EU firms for each year by replacing the interaction term Post - Treatment with separate interaction terms for each period relative to the year of the implementation of the disclosure mandate. The differences in COGS between UK and EU firms are statistically not different from zero during the pre-treatment years. For sales, we observe largely insignificant pre-treatment differences between UK and EU firms. During the post-treatment period, the point estimates are greater than zero, yet insignificant for most periods.

Taken together, the results in this section show that disclosing firms do not experience significant cost or sales increases, on average, and consequently no significant effect on gross margins. As such, our findings provide no support for the concern that GHG disclosure mandates could have a deteriorating effect on financial operating performance.

Finally, we exploit information about the complexity of a firm's installation portfolio by interacting the treatment variable with a complexity measure. Column (I) in Table 7 shows that firms with a more complex installation structure, i.e., with higher complexity scores, reduce their emissions by less than less complex firms. Columns (II) and (III) of Table 7 show that this finding is robust to using the two alternative definitions for carbon intensity. Columns (IV)-(VI) indicate that our results on operating performance are largely unaffected by including the information on firm complexity. This finding is intuitive, as firms with more complex operating structures reduce emissions to a lesser extent. We also do not expect to see any changes in gross margins, costs, or sales. In conclusion, firms with a more complex corporate structure are less successful at reducing both emissions and carbon intensity, thus providing supporting evidence for $\mathrm{H} 4$.

\section{Sensitivity and additional analyses}

In this section, we report the findings from sensitivity tests and additional analyses. For our first sensitivity test, we construct a matched sample of treatment and control firms. Accordingly, we match each treatment firm with a control group firm within the same SIC-1 industry based on average pre-treatment emission levels, i.e., a one-to-one matching without replacement. ${ }^{46}$ We use the same dependent variables as in our main tests. Table 8 presents the results and shows that our estimates are qualitatively similar to the ones obtained before. Furthermore, we use an industry-balanced sample, i.e., only firms from industries with treatment and control group observations. This approach leads to unchanged results.

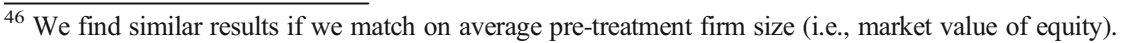


$A$

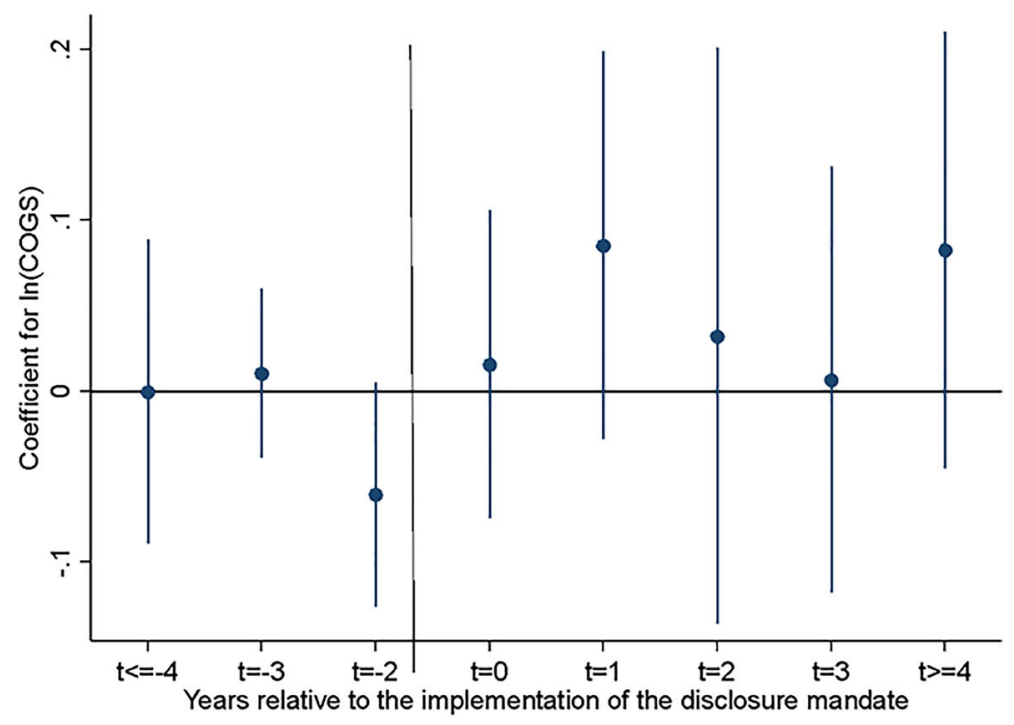

$B$

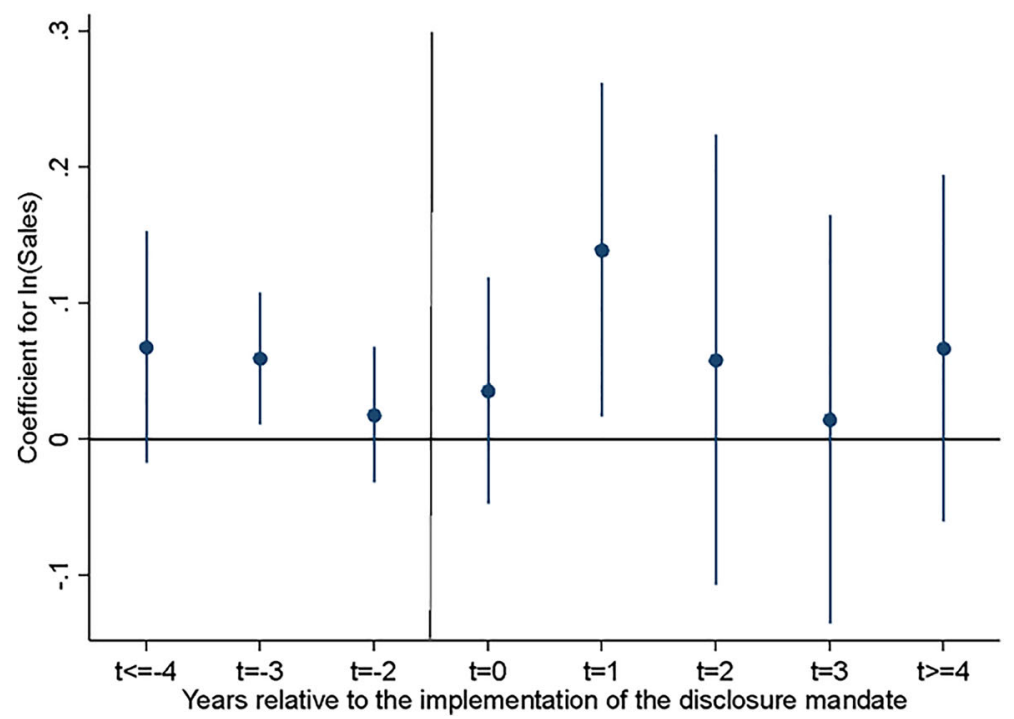

Fig. 4 Change in operating performance surrounding the disclosure mandate. Panel A: $\ln (C O G S)$. Panel B: $\ln$ (Sales). This figure shows the change in a firm's financial operating performance surrounding the disclosure mandate. Values on the y-axis show differences in the natural logarithm of emissions of treated and control group firms and $90 \%$ confidence intervals. To obtain these estimates, we replicate model (3) but replace Post . Treat with separate interaction terms for each individual period surrounding the disclosure mandate. To account for the staggered implementation of the act, we adjust time periods using relative time periods. Values on the $\mathrm{x}$-axis indicate periods relative to the first-time application of the disclosure mandate $(\mathrm{t}=0)$. For firms with fiscal year end after September 30, 2013, $t=0$ refers to the year 2013. For firms with fiscal year end before September 30, 2013, $\mathrm{t}=0$ refers to the year 2014. Periods $\mathrm{t}=-2, \mathrm{t}=-3$, and $\mathrm{t}<=-4$ are prior to the first-time application of the disclosure mandate. Periods $t=0, t=+1$, and $t>=2$ are on or after the first-time application of the disclosure mandate. We use the last year prior to the first-time application $(t=-1)$ as the benchmark period. 
We acknowledge that during our sample period France mandated broad corporate disclosures regarding environmental stewardship. While we kept French installations for our main tests, we find virtually unchanged results for emission reductions and operating performance if we exclude installations owned by French firms. Our results on emission reductions and operating performance are also robust to not excluding energy sector installations or only excluding electricity installations from our sample. As discussed in our data section, electricity installations have been subject to additional climate regulations during our observation period.

We also validate the robustness of our findings to the sample period and emission data availability: (1) we exclude the entry-into-force year of the Companies Act, (2) we do not exclude installations without emissions in a single year or maintenance during the sample period, and (3) we use a balanced sample at the firm level, i.e., we only use firms with data for all sample periods. All three approaches lead to unchanged emission results.

In concluding this section, we note that, with regard to other potentially confounding regulations within the European Union, we are unable to document either a concurring regulation or another event that would explain our results. Of course, we cannot rule out that an unspecified event, which coincided with the 2013 act and differentially affected listed firms in the UK, had a confounding effect on our findings. Finally, we only investigate the effects of one GHG emission disclosure regulation on specific firms (covered by the EU ETS) in one country (UK) for a specific period (2009-2018).

\section{Concluding remarks}

This study contributes to the growing literature on the effects of disclosure requirements for firms' activities in the ESG domain. While there appears to be considerable interest in having standardized reports on such activities, there does not seem to be a generally accepted measurement and verification framework for many ESG variables. Environmental pollution is an exception in this regard, because for many pollutants firms already have to demonstrate compliance with existing regulations. Our study on the effect of the 2013 mandate that required UK firms to disclose their greenhouse gas emissions in annual reports exploits the fact that most European manufacturing sites already had to have their reported emissions verified under the rules of the European Emission Trading scheme.

The introduction of the Companies Act 2006 (Strategic Report and Directors' Report) Regulations 2013 provides a source of exogenous variation in the disclosure regime of firms located in different countries. We find that installations belonging to UK companies subject to the disclosure mandate exhibit significant reductions in GHG emissions compared to installations in the control group, after including various timevariant and time-invariant fixed effects as well as firm specific control variables. Specifically, the treated firms reduced emissions by about $8 \%$ following the disclosure mandate, relative to pre-treatment emission levels. These results obtain at both the installation level and the firm level. We observe comparable incremental reductions in the carbon intensity of the treated firms when total emissions are scaled either by sales or cost of goods sold. Additional cross-sectional tests indicate that multinational firms with more complex operations tend to reduce their emissions by a smaller percentage than their less complex counterparts. 
Table 7 The effect of installation portfolio complexity on emission and financial operating performance

\begin{tabular}{|c|c|c|c|c|c|c|}
\hline \multirow[b]{3}{*}{ Dependent variable: } & \multicolumn{3}{|l|}{ Emissions } & \multicolumn{3}{|c|}{ Operating financial performance } \\
\hline & (I) & (II) & (III) & (IV) & $(\mathrm{V})$ & (VI) \\
\hline & $\ln ($ Emissions $)$ & $\begin{array}{l}\ln (\text { Emissions/ } \\
\text { COGS })\end{array}$ & $\begin{array}{l}\ln (\text { Emissions/ } \\
\text { Sales })\end{array}$ & $\begin{array}{l}\text { Gross } \\
\text { margin }\end{array}$ & $\ln (\mathrm{COGS})$ & $\ln ($ Sales $)$ \\
\hline \multicolumn{7}{|l|}{ Experimental variables } \\
\hline Post $\cdot$ Treat & $\begin{array}{l}-0.076 * * \\
(-3.101)\end{array}$ & $\begin{array}{l}-0.128 * * \\
(-3.181)\end{array}$ & $\begin{array}{l}-0.093 * * \\
(-2.358)\end{array}$ & $\begin{array}{l}-0.015 \\
(-1.008)\end{array}$ & $\begin{array}{l}0.067 \\
(1.537)\end{array}$ & $\begin{array}{l}0.025 \\
(0.588)\end{array}$ \\
\hline $\begin{array}{l}\text { Post } \cdot \text { Treat } \cdot \\
\text { Complexity }\end{array}$ & $\begin{array}{l}0.056 * * * \\
(3.466)\end{array}$ & $\begin{array}{l}0.085 * * \\
(3.000)\end{array}$ & $\begin{array}{l}0.085 * * \\
(2.960)\end{array}$ & $\begin{array}{l}0.000 \\
(0.111)\end{array}$ & $\begin{array}{l}-0.001 \\
(-0.019)\end{array}$ & $\begin{array}{l}-0.003 \\
(-0.087)\end{array}$ \\
\hline Post & $\begin{array}{l}0.116^{* *} \\
(2.829)\end{array}$ & $\begin{array}{l}0.125 * * \\
(2.609)\end{array}$ & $\begin{array}{l}0.085^{*} \\
(1.943)\end{array}$ & $\begin{array}{l}0.017 * \\
(2.081)\end{array}$ & $\begin{array}{l}-0.005 \\
(-0.202)\end{array}$ & $\begin{array}{l}0.032 \\
(1.271)\end{array}$ \\
\hline Post $\cdot$ Complexity & $\begin{array}{l}-0.003 \\
(-0.218)\end{array}$ & $\begin{array}{l}-0.010 \\
(-0.474)\end{array}$ & $\begin{array}{l}0.003 \\
(0.144)\end{array}$ & $\begin{array}{l}-0.008 \\
(-1.413)\end{array}$ & $\begin{array}{l}0.007 \\
(0.460)\end{array}$ & $\begin{array}{l}-0.005 \\
(-0.462)\end{array}$ \\
\hline \multicolumn{7}{|l|}{ Control variables } \\
\hline Size & $\begin{array}{l}-0.007 \\
(-0.281)\end{array}$ & $\begin{array}{l}-0.227 * * * \\
(-4.420)\end{array}$ & $\begin{array}{l}-0.273 * * * \\
(-5.355)\end{array}$ & $\begin{array}{l}0.021 * * * \\
(3.267)\end{array}$ & $\begin{array}{l}0.201 * * * \\
(3.983)\end{array}$ & $\begin{array}{l}0.247 * * * \\
(4.995)\end{array}$ \\
\hline Asset intensity & $\begin{array}{l}0.381 \\
(1.416)\end{array}$ & $\begin{array}{l}0.473 \\
(0.956)\end{array}$ & $\begin{array}{l}0.491 \\
(1.082)\end{array}$ & $\begin{array}{l}0.014 \\
(0.256)\end{array}$ & $\begin{array}{l}-0.170 \\
(-0.468)\end{array}$ & $\begin{array}{l}-0.137 \\
(-0.427)\end{array}$ \\
\hline Leverage & $\begin{array}{l}-0.133 \\
(-0.376)\end{array}$ & $\begin{array}{l}-1.017 * * * \\
(-3.378)\end{array}$ & $\begin{array}{l}-0.839 * * \\
(-2.555)\end{array}$ & $\begin{array}{l}-0.069 \\
(-1.188)\end{array}$ & $\begin{array}{l}0.844 * * * \\
(4.766)\end{array}$ & $\begin{array}{l}0.678 * * * \\
(5.060)\end{array}$ \\
\hline Price-to-Book & $\begin{array}{l}-0.005 \\
(-0.794)\end{array}$ & $\begin{array}{l}0.041 * * * \\
(4.452)\end{array}$ & $\begin{array}{l}0.043 * * * \\
(4.270)\end{array}$ & $\begin{array}{l}-0.001 \\
(-0.813)\end{array}$ & $\begin{array}{l}-0.044 * * * \\
(-3.300)\end{array}$ & $\begin{array}{l}-0.047 * * * \\
(-3.387)\end{array}$ \\
\hline$G D P$ & $\begin{array}{l}-0.221 * \\
(-1.861)\end{array}$ & $\begin{array}{l}-0.627 * * \\
(-2.854)\end{array}$ & $\begin{array}{l}-0.419 * \\
(-2.034)\end{array}$ & $\begin{array}{l}-0.154 * * \\
(-2.309)\end{array}$ & $\begin{array}{l}0.414^{*} \\
(2.206)\end{array}$ & $\begin{array}{l}0.250 \\
(1.747)\end{array}$ \\
\hline Input prices & $\begin{array}{l}-0.239 \\
(-0.654)\end{array}$ & $\begin{array}{l}-0.389 \\
(-0.579)\end{array}$ & $\begin{array}{l}-0.297 \\
(-0.528)\end{array}$ & $\begin{array}{l}-0.096 \\
(-1.210)\end{array}$ & $\begin{array}{l}0.162 \\
(0.365)\end{array}$ & $\begin{array}{l}0.083 \\
(0.204)\end{array}$ \\
\hline Industry trends & yes & yes & yes & yes & yes & yes \\
\hline Firm fixed effects & yes & yes & yes & yes & yes & yes \\
\hline Year fixed effects & yes & yes & yes & yes & yes & yes \\
\hline Observations & 1,257 & 1,257 & 1,257 & 1,257 & 1,257 & 1,257 \\
\hline Adjusted $R^{2}$ & 0.987 & 0.982 & 0.983 & 0.905 & 0.988 & 0.990 \\
\hline
\end{tabular}

This table presents the results of estimating the effect of a GHG disclosure mandate on GHG emissions and financial operating performance depending on a firm's installation portfolio complexity (model (4)). The dependent variables in columns (I)-(III) indicate a firm's emissions and carbon intensity. The dependent variables in columns (IV)-(VI) indicate financial operating performance. Reported values are coefficients and t-statistics in parentheses. Variables are defined in Table 1. All continuous variables are winsorized at the 1st and 99th percentiles. $* * *, * *$, and $*$ indicate significance at $0.01,0.05$, and 0.1 levels, respectively. Standard errors are clustered by country and year

With regard to financial consequences, we find that in the years following the mandate the treated firms experienced a small, but statistically insignificant, increase in both their production costs and their sales. The latter effect is consistent with the interpretation of firms having improved their public image with customers on account of having improved a central CSR variable. Since the small and statistically insignificant increases in both revenues and 
Table 8 Results for matched sample

\begin{tabular}{|c|c|c|c|c|c|c|}
\hline \multirow[b]{3}{*}{$\begin{array}{l}\text { Dependent } \\
\text { variable: }\end{array}$} & \multicolumn{3}{|l|}{ Emissions } & \multicolumn{3}{|c|}{ Operating financial performance } \\
\hline & (I) & (II) & (III) & (IV) & $(\mathrm{V})$ & (VI) \\
\hline & $\ln ($ Emissions $)$ & $\begin{array}{l}\ln (\text { Emissions/ } \\
\text { COGS })\end{array}$ & $\begin{array}{l}\ln (\text { Emissions/ } \\
\text { Sales })\end{array}$ & $\begin{array}{l}\text { Gross } \\
\text { margin }\end{array}$ & $\ln (\mathrm{COGS})$ & $\ln ($ Sales $)$ \\
\hline \multicolumn{7}{|c|}{ Experimental variables } \\
\hline Post $\cdot$ Treat & $\begin{array}{l}-0.105^{* * * *} \\
(-4.228)\end{array}$ & $\begin{array}{l}-0.167^{*} \\
(-2.024)\end{array}$ & $\begin{array}{l}-0.133 * * \\
(-2.733)\end{array}$ & $\begin{array}{l}-0.020 \\
(0.473)\end{array}$ & $\begin{array}{l}0.070 \\
(0.396)\end{array}$ & $\begin{array}{l}0.024 \\
(0.611)\end{array}$ \\
\hline Post & $\begin{array}{l}0.212^{* * * *} \\
(4.372)\end{array}$ & $\begin{array}{l}0.252 * * * \\
(4.749)\end{array}$ & $\begin{array}{l}0.187 * * * \\
(4.276)\end{array}$ & $\begin{array}{l}0.033 \\
(0.123)\end{array}$ & $\begin{array}{l}-0.055 \\
(0.219)\end{array}$ & $\begin{array}{l}0.017 \\
(0.623)\end{array}$ \\
\hline \multicolumn{7}{|l|}{ Control variables } \\
\hline Size & $\begin{array}{l}0.029 * * \\
(2.655)\end{array}$ & $\begin{array}{l}-0.158 * * * \\
(-3.417)\end{array}$ & $\begin{array}{l}-0.228 * * * \\
(-5.933)\end{array}$ & $\begin{array}{l}0.035 * * \\
(0.040)\end{array}$ & $\begin{array}{l}0.139 * * \\
(0.017)\end{array}$ & $\begin{array}{l}0.212 * * * \\
(0.001)\end{array}$ \\
\hline Asset intensity & $\begin{array}{l}0.449 \\
(1.387)\end{array}$ & $\begin{array}{l}0.701 \\
(1.338)\end{array}$ & $\begin{array}{l}0.898^{*} \\
(2.291)\end{array}$ & $\begin{array}{l}-0.073 \\
(0.402)\end{array}$ & $\begin{array}{l}-0.337 \\
(0.309)\end{array}$ & $\begin{array}{l}-0.425 \\
(0.126)\end{array}$ \\
\hline Leverage & $\begin{array}{l}0.287 \\
(0.593)\end{array}$ & $\begin{array}{l}-0.933^{*} \\
(-1.994)\end{array}$ & $\begin{array}{l}-0.740 \\
(-1.733)\end{array}$ & $\begin{array}{l}-0.048 \\
(0.462)\end{array}$ & $\begin{array}{l}1.104 * * * \\
(0.002)\end{array}$ & $\begin{array}{l}0.940 * * * \\
(0.001)\end{array}$ \\
\hline Price-to-Book & $\begin{array}{l}0.001 \\
(0.055)\end{array}$ & $\begin{array}{l}0.046^{* *} \\
(2.350)\end{array}$ & $\begin{array}{l}0.047 * * \\
(2.424)\end{array}$ & $\begin{array}{l}-0.001 \\
(0.314)\end{array}$ & $\begin{array}{l}-0.041^{* * *} \\
(0.010)\end{array}$ & $\begin{array}{l}-0.044 * * * \\
(0.004)\end{array}$ \\
\hline$G D P$ & $\begin{array}{l}-0.064 \\
(-0.309)\end{array}$ & $\begin{array}{l}-1.024^{*} \\
(-1.947)\end{array}$ & $\begin{array}{l}-0.622 \\
(-1.174)\end{array}$ & $\begin{array}{l}-0.175 \\
(0.254)\end{array}$ & $\begin{array}{l}0.992 * * \\
(0.032)\end{array}$ & $\begin{array}{l}0.710^{*} \\
(0.098)\end{array}$ \\
\hline Input prices & $\begin{array}{l}0.069 \\
(0.098)\end{array}$ & $\begin{array}{l}0.110 \\
(0.107)\end{array}$ & $\begin{array}{l}0.297 \\
(0.278)\end{array}$ & $\begin{array}{l}-0.100 \\
(0.540)\end{array}$ & $\begin{array}{l}-0.100 \\
(0.890)\end{array}$ & $\begin{array}{l}-0.221 \\
(0.752)\end{array}$ \\
\hline Industry trends & yes & yes & yes & yes & yes & yes \\
\hline Firm fixed effects & yes & yes & yes & yes & yes & yes \\
\hline Year fixed effects & yes & yes & yes & yes & yes & yes \\
\hline Observations & 472 & 472 & 472 & 472 & 472 & 472 \\
\hline Adjusted $R^{2}$ & 0.982 & 0.981 & 0.983 & 0.937 & 0.990 & 0.992 \\
\hline
\end{tabular}

This table presents the results of estimating the effect of a GHG disclosure mandate on GHG emissions and operating performance. We use a one-to-one matching without replacement on pre-treatment emissions for firms within the same SIC-1 industry. Reported values are coefficients and $p$-values in parentheses. Variables are defined in Table 1. All continuous variables are winsorized at the 1st and 99th percentiles. ***,**, and * indicate significance at $0.01,0.05$, and 0.1 levels, respectively. Standard errors are clustered by country and year

costs net out to a zero effect in the gross margins, our results indicate that the disclosure mandate did not have a deteriorating effect on the financial operating performance of the firms subject to the act.

The emissions data for the firms in our treatment group had already been publicly available prior to the UK mandate, albeit in a distributed form, so outside observers had to incur search costs in order to assign installation-level emissions to publicly listed firms. Our empirical findings are consistent with the hypothesis that the disclosure requirement made firm-specific carbon footprint information directly accessible to stakeholders and thus resulted in additional transparency, which motivated the firms' management to achieve greater emission reductions. 
In the current debate about alternative policy tools for addressing the impending climate crisis, economists generally point to pricing carbon emissions or subsidizing low-carbon energy alternatives. The findings in this paper indicate that the increased transparency associated with greenhouse gas reporting mandates, like the 2013 act in the UK, could be another policy lever for reducing corporate carbon emissions.

\section{Appendix A: Reporting items for the Strategic Report according to The Companies Act 2006 (Strategic Report and Directors' Report) Regulations 2013}

Disclosure requirement

Section of the Act

Annual quantity of emissions in tonnes of carbon dioxide equivalent from activities for P. 7, 15. (2) which that company is responsible including the combustion of fuel; and the operation of any facility (listed firms)

Annual quantity of emissions in tonnes of carbon dioxide equivalent resulting from the purchase of electricity, heat, steam or cooling by the company for its own use (listed firms)

Methodologies used to calculate the information on carbon dioxide equivalents (listed firms)

At least one ratio which expresses the quoted company's annual emissions in relation to a quantifiable factor associated with the company's activities (listed firms)

Not only the information required by paragraphs 15(2) and (3) and 17, but also that information as disclosed in the report for the preceding financial year.

Description of the company's strategy (listed firms)

Description of the company's business model (listed firms)

P. 7, 16.

P. $17,17$.

P. $17,18$.

Ch. 4A, 414C (8) (a)

Ch. 4A, 414C (8) (b)

A breakdown showing at the end of the financial year the number of persons of each sex who were directors of the company (listed firms)

Ch. 4A, 414C (8) (c)

A breakdown showing at the end of the financial year the number of persons of each sex who were senior managers of the company (listed firms)

Ch. 4A, 414C (8) (c)

A breakdown showing at the end of the financial year the number of persons of each sex who were employees of the company (listed firms)

Ch. 4A, 414C (8) (c)

Fair review of the company's business

Description of the principal risks and uncertainties facing the company

Ch. 4A, 414C (2) (a)

Ch. 4A, 414C (2) (b)

Ch 4A, 414C (3) (a) business

Balanced and comprehensive analysis of the position of the company's business at the end of the year

Analysis using financial key performance indicators

Ch. $4 \mathrm{~A}, 414 \mathrm{C}(3)$ (b)

Ch. 4A, 414C (4) (a)

Where appropriate: analysis using other key performance indicators, including information relating to environmental matters and employee matters

Ch. 4A, 414C (4) (b)

To the extent necessary for an understanding of the development, performance or position of the company's business: main trends and factors likely to affect the future development, performance and position (listed firms)

To the extent necessary for an understanding of the development, performance or position of the company's business: information about environmental matters (including the impact of the company's business on the environment) including information about any policies of the company in relation to those matters and the effectiveness of those policies (listed firms)

Ch. 4A, 414C (7) (a)

Ch. 4A, 414C (7)

(b) (i) 
To the extent necessary for an understanding of the development, performance or Ch. 4A, 414C (7) position of the company's business: information about the company's employees (b) (ii) including information about any policies of the company in relation to those matters and the effectiveness of those policies (listed firms)

To the extent necessary for an understanding of the development, performance or position of the company's business: information about social, community and human rights issues including information about any policies of the company in relation to those matters and the effectiveness of those policies (listed firms)

This table provides a detailed overview of all new disclosure requirements of The Companies Act 2006 (Strategic Report and Directors' Report) Regulations 2013. The first column shows the newly required disclosure in the strategic report. The second column shows the section of the act.

\section{Appendix B: Major changes in the EU ETS regulation surrounding the introduction of the third trading period in 2013}

Two key changes to the design of the EU ETS took place in the third trading period. First, an EU-wide cap was introduced, stipulating a decrease by $1.74 \%$ each year relative to a pre-specified baseline emission level. Second, whereas until 2012 almost all allowances were allocated free of charge, a greater share of allowances was auctioned starting in 2013. These changes could potentially call into question the causal effect of the act, if the changes in the ETS system differentially affected UK firms compared to firms in the control group.

With respect to the introduction of the EU-wide cap, this change was intended to decrease the political cost of decentralized cap-setting coordinated by the European Commission (see, e.g., Ellerman et al. 2016). Since allowances could be traded across the EU without any restrictions, as they could prior to 2013, there is no reason to believe that UK firms had either advantages or disadvantages with respect to their regulatory burden due to the change in cap setting, compared to firms in other EU countries.

Regarding the shift toward a greater share of allowances being auctioned, we note that the electricity sector was primarily affected by this development, with power generators in the majority of European countries losing the vast majority of their free allocation in 2013. However, as we exclude the power sector from the empirical analysis in this paper due to the potential bias stemming from the introduction of the UK Carbon Price Floor in 2013 (as explained in Section 3.5), the rise of allowance auctioning for power generators is not a concern for our analysis.

In the industrial sectors, which are the focus of this paper, free allocation continued to be the dominant form of distributing the aggregate emissions cap. About $97 \%-98 \%$ of industrial emissions were represented by sectors that were deemed to be at risk of carbon leakage during the period after 2013. The firms in this sector therefore received their full allotment of free allowances (ECA 2020). As the vast majority of the industrial sector's emissions continued to be covered by free allowances, there is no 
indication that UK firms were subject to advantages or disadvantages in comparison to firms from other EU countries.

Funding Open Access funding enabled and organized by Projekt DEAL.

Data availability Publicly available from the sources cited in the text.

Open Access This article is licensed under a Creative Commons Attribution 4.0 International License, which permits use, sharing, adaptation, distribution and reproduction in any medium or format, as long as you give appropriate credit to the original author(s) and the source, provide a link to the Creative Commons licence, and indicate if changes were made. The images or other third party material in this article are included in the article's Creative Commons licence, unless indicated otherwise in a credit line to the material. If material is not included in the article's Creative Commons licence and your intended use is not permitted by statutory regulation or exceeds the permitted use, you will need to obtain permission directly from the copyright holder. To view a copy of this licence, visit http://creativecommons.org/licenses/by/4.0/.

\section{References}

Air Resources Board. 2016. Regulation for the California cap on greenhouse gas emissions and market-based compliance mechanisms.

Anderson, B., and C. Di Maria. 2011. Abatement and allocation in the pilot phase of the EU ETS. Environmental and Resource Economics 48: 83-103. https://doi.org/10.1007/s10640-010-9399-9.

Bel, G., and S. Joseph. 2015. Emission abatement: Untangling the impacts of the EU ETS and the economic crisis. Energy Economics 49: 531-539. https://doi.org/10.1016/j.eneco.2015.03.014.

Bertrand, M., and S. Mullainathan. 2003. Enjoying the quiet life? Corporate governance and managerial preferences. Journal of Political Economy 111: 1043-1075. https://doi.org/10.1086/376950.

Biddle, G.C., and G. Hilary. 2006. Accounting quality and firm-level capital investment. The Accounting Review 81: 963-982. https://doi.org/10.2308/accr.2006.81.5.963.

Biddle, G.C., G. Hilary, and R.S. Verdi. 2009. How does financial reporting quality relate to investment efficiency? Journal of Accounting and Economics 48: 112-131. https://doi.org/10.1016/j.jacceco.2009. 09.001.

Broadstock, D.C., A. Collins, L.C. Hunt, and K. Vergos. 2018. Voluntary disclosure, greenhouse gas emissions and business performance: Assessing the first decade of reporting. British Accounting Review 50: 48-59. https://doi.org/10.1016/j.bar.2017.02.002.

CDP. 2017. New report shows just 100 companies are source of over $70 \%$ of emissions. https://www.cdp.net/ en/articles/media/new-report-shows-just-100-companies-are-source-of-over-70-of-emissions.

Chen, Y.-C., M. Hung, and Y. Wang. 2018. The effect of mandatory CSR disclosure on firm profitability and social externalities: Evidence from China. Journal of Accounting and Economics 65: 169-190. https://doi. org/10.1016/j.jacceco.2017.11.009.

Cheng, M., D. Dhaliwal, and Y. Zhang. 2013. Does investment efficiency improve after the disclosure of material weaknesses in internal control over financial reporting? Journal of Accounting and Economics 56: 1-18. https://doi.org/10.1016/j.jacceco.2013.03.001.

Christensen, H.B., E. Floyd, L.Y. Liu, and M.G. Maffett. 2017. The real effects of mandated information on social responsibility in financial reports: Evidence from mine-safety records. Journal of Accounting and Economics 64: 284-304. https://doi.org/10.1016/j.jacceco.2017.08.001.

DECC. 2016. Department of Energy \& climate change: 2014 UK greenhouse gas emissions, final figures. Statistical release.

Dechezleprêtre, A., C. Genaioli, R. Martin, and M. Muûls. 2019. Searching for carbon leaks in multinational companies. Centre for Climate Change Economics and Policy Working Paper No. 165.

DEFR. 2013. Environmental reporting guidelines: Including mandatory greenhouse gas emissions reporting guidance.

DEFRA. 2010. The contribution that reporting of greenhouse gas emissions makes to the UK meeting its climate change objectives: A review of the current evidence. https://assets.publishing.service.gov.uk/ government/uploads/system/uploads/attachment_data/file/69262/pb13449-corporate-reporting-101130. pdf. 
Drucker, P.F. 1954. The practice of management. Harper Business.

ECA. 2020. The EU's Emissions Trading System: free allocation of allowances needed better targeting. https://www.eca.europa.eu/en/Pages/DocItem.aspx?did=54392.

Ellerman, A.D., F.J. Convery, C. de Perthuis, E. Alberola, B.K. Buchner, A. Delbosc, et al. 2010. Pricing carbon. Cambridge University Press.

Ellerman, A.D., C. Marcantonini, and A. Zaklan. 2016. The European Union emissions trading system: Ten years and counting. Review of Environmental Economics and Policy 10: 89-107. https://doi.org/10.1093/ reep/rev014.

EPA. 2019. U.S. Environmental Protection Agency. Sulfur dioxide basics. https://www.epa.gov/so2-pollution/ sulfur-dioxide-basics.

Ernstberger, J., B. Link, M. Stich, and O. Vogler. 2017. The real effects of mandatory quarterly reporting. The Accounting Review 92: 33-60. https://doi.org/10.2308/accr-51705.

European Commission. 2015. EU ETS Handbook.

Fiechter, P., J.-M. Hitz, and N. Lehmann. 2020. Real effects in anticipation of mandatory disclosures: Evidence from the European Union's CSR directive. Working Paper.

Friedman, H.L., and M.S. Heinle. 2016. Taste, information, and asset prices: Implications for the valuation of CSR. Review of Accounting Studies 21: 740-767. https://doi.org/10.1007/s11142-016-9359-x.

Fung, A., D. Weil, and M. Graham. 2007. Full disclosure: The perils and promise of transparency. Cambridge University Press.

Graham, J.R., M. Hanlon, and T. Shevlin. 2011. Real effects of accounting rules: Evidence from multinational firms' investment location and profit repatriation decisions. Journal of Accounting Research 49: 137-185. https://doi.org/10.1111/j.1475-679X.2010.00395.x.

Granja, J. 2018. Disclosure regulation in the commercial banking industry: Lessons from the national banking era. Journal of Accounting Research 56: 173-216. https://doi.org/10.1111/1475-679X.12193.

Grewal, J. 2021. Real effects of disclosure regulation on voluntary disclosers. Journal of Accounting and Economics (in press). https://doi.org/10.1016/j.jacceco.2021.101390.

Grewal, J., E.J. Riedl, and G. Serafeim. 2019. Market reaction to mandatory nonfinancial disclosure. Management Science 65: 3061-3084. https://doi.org/10.1287/mnsc.2018.3099.

Grewal, J., and G. Serafeim. 2020. Research on corporate sustainability: Review and directions for future research. Foundations and Trends® in Accounting 14: 73-127.

Heinkel, R., A. Kraus, and J. Zechner. 2001. The effect of green investment on corporate behavior. Journal of Financial and Quantitative Analysis 36: 431-449. https://doi.org/10.2307/2676219.

Hirst, D. 2018. Carbon Price floor (CPF) and the price support mechanism.

Hombach, K., and T. Sellhorn. 2019. Shaping corporate actions through targeted transparency regulation: A framework and review of extant evidence. Schmalenbach Business Review 71: 137-168. https://doi.org/ 10.1007/s41464-018-0065-z.

InsideIreland.ie. 2009. Carbon tax of $€ 15$ a tonne announced. https://web.archive.org/web/20120328031928/ http://insideireland.ie/2009/12/09/archive2313-2373/.

IPCC. 2018. Global warming of $1.5^{\circ} \mathrm{C}$. https://www.ipcc.ch/sr15/.

Jouvenot, V., and P. Krueger. 2020. Reduction in corporate greenhouse gas emissions under prescriptive disclosure requirements. Working Paper.

Kanodia, C. 2007. Accounting disclosure and real effects. Foundations and Trends® in Accounting 1: 167258. https://doi.org/10.1561/1400000003.

Kaplan, R.S., and S.R. Anderson. 2007. Time-driven activity-based costing: A simpler and more powerful path to higher profits. Harvard Business School Press.

Kraft, A.G., R. Vashishtha, and M. Venkatachalam. 2018. Frequent financial reporting and managerial myopia. The Accounting Review 93: 249-275. https://doi.org/10.2308/accr-51838.

Kraus, A., and R. Amir. 2010. Reducing managers' incentives to cannibalize: Managerial stock options when shareholders are diversified. Journal of Financial Intermediation 19: 439-460. https://doi.org/10.1016/j. jfi.2009.05.001.

Martin, R., M. Muûls, and U.J. Wagner. 2016. The impact of the European Union emissions trading scheme on regulated firms: What is the evidence after ten years? Review of Environmental Economics and Policy 10: 129-148. https://doi.org/10.1093/reep/rev016.

McKinsey. 2009. Pathways to a low-carbon economy - Version 2 of the global greenhouse gas abatement cost curve. McKinsey \& Company.

Muller, N.Z., R. Mendelsohn, and W. Nordhaus. 2011. Environmental accounting for pollution in the United States economy. American Economic Review 101: 1649-1675. https://doi.org/10.1093/reep/rev016. 
Murray, B.C., and P.T. Maniloff. 2015. Why have greenhouse emissions in RGGI states declined? An econometric attribution to economic, energy market, and policy factors. Energy Economics 51: 581589. https://doi.org/10.1016/j.eneco.2015.07.013.

PwC and CDP. 2010. Review of the contribution of reporting to GHG emissions reductions and associated costs and benefits: Report to the Department for Environment, Food and Rural Affairs.

Reichelstein, S., and D. Bebb. 2016. Sustainable investing at generation investment management (case no.SM257).

Reichelstein, S., and D. W. Hoyt. 2011. REI's solar energy program (case no.BE17).

RGGI. 2013. Model rule part XX CO2 budget trading program. Originally issued Feb 7, 2013. Revised Dec 23, 2013.

Roberts, M. R., and T. M. Whited. 2013. Endogeneity in empirical corporate finance. In Handbook of the Economics of Finance (Vol. 2, pp. 493-572). Elsevier.

Serfling, M. 2016. Firing costs and capital structure decisions. The Journal of Finance 71: 2239-2286. https:// doi.org/10.1111/jofi.12403.

Shroff, N. 2017. Corporate investment and changes in GAAP. Review of Accounting Studies 22: 1-63. https:// doi.org/10.1007/s11142-016-9375-x.

Shroff, N., R.S. Verdi, and G. Yu. 2014. Information environment and the investment decisions of multinational corporations. The Accounting Review 89: 759-790. https://doi.org/10.2308/accr-50643.

Sprouse, W. 2020. BlackRock CEO: Climate change is causing a 'fundamental reshape of finance. $C F O$ Magazine.

Stern, N. 2006. Stern review on the economics of climate change. Government of the United Kingdom.

Sullivan, R., and A. Gouldson. 2012. Does voluntary carbon reporting meet investors' needs? Journal of Cleaner Production 36: 60-67. https://doi.org/10.1016/j.jclepro.2012.02.020.

Tomar, S. 2019. CSR disclosure and benchmarking-learning: Emissions responses to mandatory greenhouse gas disclosure. Working Paper.

Trucost. 2009. Carbon risks in UK equity funds: Trucost study of the carbon footprints of portfolios and carbon management in pension fund assets.

Young, S.D., and S.F. O’Byrne. 2001. EVA and value-based management: A practical guide to implementation. McGraw-Hill.

Publisher's note Springer Nature remains neutral with regard to jurisdictional claims in published maps and institutional affiliations.

\section{Affiliations}

\section{Benedikt Downar ${ }^{1}$ • Jürgen Ernstberger ${ }^{1}$ - Stefan Reichelstein ${ }^{2,3} \cdot$ Sebastian $^{2}$ Schwenen ${ }^{1}$. Aleksandar Zaklan ${ }^{4}$}

1 School of Management, Technical University of Munich, Munich, Germany

2 University of Mannheim, Mannheim, Germany

3 Stanford Graduate School of Business, Stanford, CA, USA

4 German Institute for Economic Research, DIW Berlin, Berlin, Germany 